\title{
Short-distance distribution patterns of testate amoebae in an Arctic ice-wedge polygon mire (Berelekh-Indigirka lowlands, NE Siberia)
}

\author{
Pim de Klerk ${ }^{1,2}$ (D) Anatoly Bobrov ${ }^{3} \cdot$ Martin Theuerkauf $^{2}$ (D) $\cdot$ Hans Joosten $^{2}$ (D)
}

Received: 13 May 2019 / Revised: 25 May 2020 / Accepted: 25 June 2020 / Published online: 1 August 2020

(c) The Author(s) 2020

\begin{abstract}
The Arctic is experiencing substantial warming with possibly large consequences for global climate when its large soil carbon stocks are mobilized. Yet the functioning of permafrost peatlands, which contain considerable amounts of carbon, is still not fully understood. Palaeoecological studies may contribute to unravelling this functioning but require actuo-ecological calibration of the environmental proxies used. Testate amoebae may be valuable proxies for palaeoecological reconstruction, but indeed still large gaps exist regarding their present-day distribution in Arctic peatlands. This study presents the distribution of testate amoebae taxa with high $(1 \mathrm{~m})$ spatial resolution along a transect crossing an Arctic ice-wedge polygon mire. Whereas the polygon ridges are characterised by taxa that are known to be typical of dry environments or hydrologically indifferent, the low-lying wet settings show a mixture of wet- and dry-living taxa, indicating seasonally rapidly changing conditions. High testate amoebae concentrations were only found on the dry polygon ridges. Archerella flavum occurs in various moss species in drier polygon settings, in contrast to temperate regions where the species is exclusively known from wet sites with Sphagnum, which probably relates to the special moisture conditions associated with permafrost. To compare the results of full testate amoebae analysis with those of palynology, each surface sample was split into two parts and prepared and analysed following standard testate amoebae analysis and palynological methods, respectively. Clear differences in qualitative content were found and can be attributed to the different preparation methods and to possible small $(\mathrm{a}$ few $\mathrm{cm})$ differences in sample location. Nevertheless, the indicative value of testate amoebae found in pollen samples adds importantly to the ecological inference of palynological studies. Overall testate amoebae research is very valuable for the recognition of past ecological settings and the accurate reconstruction of past hydrological regimes in Arctic mires. Considerably more research is, however, necessary to cover the total (ecological) diversity of testate amoebae populations in NE Siberia.
\end{abstract}

Keywords Actuo-ecology $\cdot$ Arctic $\cdot$ Ice-wedge polygon mires $\cdot$ NE Siberia $\cdot$ Surface samples $\cdot$ Testate amoebae

\section{Introduction}

The Arctic is currently undergoing climate warming at a rate that is double the global average (e.g. Screen et al. 2012; Meyer et al. 2015; cf. Streletskiy et al. 2015). The northern

Dedicated to the memory of Richard Payne (1978-2019), a grandmaster of testate amoebae research.

Pim de Klerk

pimdeklerk@email.de

1 State Museum of Natural History Karlsruhe, Erbprinzenstraße 13, 76133 Karlsruhe, Germany

2 Institute of Botany and Landscape Ecology, Greifswald University, partner in the Greifswald Mire Centre, Soldmannstraße 15, 17487 Greifswald, Germany

3 Department of Soil Science, Moscow State University, Vorobievy Gory, Moscow, Russia 119991 circumpolar permafrost region contains around $50 \%$ of the estimated global soil organic carbon pool, which is equivalent to twice the current atmospheric content (Kuhry et al. 2013; Hugelius et al. 2014; Abbott et al. 2016). A substantial part of the Arctic carbon is found in peatlands (Swindles et al. 2015a; Joosten 2019), and carbon released as result of permafrost thawing and associated peatland degradation may provide a positive feedback to further global warming (cf. Schädel et al. 2016; Abbott et al. 2016; Joosten 2019).

Ice-wedge polygon mires are the most prominent peatland types of the Arctic. They develop as a result of frost cracking 
and ice-wedge growth leading to polygonal systems of small ridges enclosing wet depressions of 10-30 m diameter (lowcentre polygons; cf. Billings and Peterson 1980; Zoltai and Pollet 1983; Minke et al. 2007; Kanevskiy et al. 2017). Icewedge polygons are highly dynamic with regular degradation and regeneration of ridges resulting from the complex interplay of external and internal forcing, direct and indirect effects, and positive and negative feedback mechanisms (Minke et al. 2007; De Klerk et al. 2011, 2018; Liljedahl et al. 2016). Degradation of polygon ridges may eventually result in a relief inversion: the ridges collapse and form large deep troughs and the previous central depressions become elevated elements (high-centre polygons; see Billings and Peterson 1980; Minke et al. 2007).

The complexity of the interacting processes makes it difficult to predict how polygon mires will develop under climate change, and whether they will become net sinks or sources of greenhouse gasses. Palaeoecological research may unravel past development dynamics and provide a better understanding of the present and future polygon mire landscape (De Klerk et al. 2011, 2018; Zibulski et al. 2013; Teltewskoi et al. 2016; Sim et al. 2019).

Testate amoebae are important indicators of environmental conditions, especially of moisture (Chardez 1965; Grospietsch 1972; Charman et al. 2000; Mitchell et al. 2008), but also $\mathrm{pH}$ (Payne et al. 2006; Mazei and Tsyganov 2007/2008; Lamentowicz et al. 2007, 2011), trophy (Lamentowicz et al. 2007, 2013), nitrogen (Mitchell and Gilbert 2004), sulphur (Payne 2012), phosphate (Patterson et al. 2012), organic content (Lamentowicz et al. 2013), plant functional types (Jassey et al. 2014), fire (Marcisz et al. 2015), and various other chemical and soil variables (Mazei and Tsyganov 2007/2008; Lamentowicz et al. 2008, 2011). Therefore testate amoebae analysis is increasingly used in palaeoecological research. Teltewskoi et al. (2016) compared the value of various palaeoecological parameters-including pollen and macrofossils, sediment grain size, geochemistry, and testate amoebae-for reconstructing the past hydrology of ice-wedge polygons. They concluded that testate amoebae - next to macrofossils - are the most promising proxies to reflect humidity conditions, but that their indicator value is still limited because of lack of actuo-ecological calibration studies. The observation that climate warming leads to reduced $\mathrm{C}$ fixation because of the decreasing testate amoebae biomass (Jassey et al. 2015) furthermore underlines their functional role in Arctic mire development.

Testate amoebae are unicellular protists that build a test/ shell from proteinaceous, calcareous or siliceous material, and are abundant in all kinds of aquatic (open water and littoral), telmatic and dry soil environments (Chardez 1965; Grospietsch 1972; Beyens and Meisterfeld 2001; Charman 2001; Mitchell et al. 2008; Payne 2013). Taxonomy is almost completely based on shell morphology (Charman et al. 2000; Clarke 2003; Mazei and Tsyganov 2006), which is not necessarily linked to phylogeny (e.g. Heger et al. 2013; Payne 2013; Oliverio et al. 2014; Kosakyan et al. 2016). One and the same taxon may-within its genetic/ physiologic constraints-develop different shell shapes in different ecological settings (Schönborn 1992; Bobrov et al. 2002; Dallimore 2004; Oliverio et al. 2014; Kosakyan et al. 2016). This notion implies that - if it is known how various environmental factors influence morphology-ecological conditions in the past can be inferred very accurately from morphological characteristics.

Testate amoebae have proven to be very valuable for understanding (sub-)Arctic environments (Beyens and Bobrov 2016) in NW Europe (Tsyganov et al. 2012a, 2013; Swindles et al. 2015a, b), Svalbard and Jan Mayen (Beyens et al. 1986a, b; Beyens and Chardez 1987; Mazei et al. 2018a, b), Greenland (Mattheeussen et al. 2005; Tsyganov et al. 2011, 2012b, c), Arctic Canada (Dallimore 2004; Lamarre et al. 2013; Sim et al. 2019), Alaska (Payne et al. 2006; Wetterich et al. 2012; Gałka et al. 2018; Taylor et al. 2019), and Arctic Russia outside Siberia (Mazei et al. 2018c). Various palaeoecological studies in Arctic NE Siberia include testate amoebae analysis (e.g. Schirrmeister et al. 2002, 2011; Andreev et al. 2004; Bobrov et al. 2004, 2009; Müller et al. 2009; Bobrov and Wetterich 2012; Teltewskoi et al. 2016), yet actuo-ecological calibration studies that cover the short-distance variation of polygon microrelief elements have hardly been carried out in this area (e.g. Bobrov et al. 2013). These are, however, necessary for a more accurate interpretation of fossil assemblages in palaeoprofiles (Teltewskoi et al. 2016).

This paper presents the results of the study of a 25-m-long surface sample transect through a NE Siberian ice-wedge polygon of which samples were analysed every meter and compared with available data from a nearby polygon (Bobrov et al. 2013). Furthermore, the paper tests to what extent palynological analysis-that normally reveals only few testate amoebae taxa-is an alternative to full testate amoebae analysis.

\section{Materials and methods}

\section{Study area}

The studied ice-wedge polygon Lhc11 $\left(70^{\circ} 49^{\prime} 50^{\prime \prime} \mathrm{N}, 147^{\circ}\right.$ $28^{\prime} 52^{\prime \prime} \mathrm{E}$ ) is located near the Kytalyk scientific station, c. $30 \mathrm{~km}$ northwest of Chokurdakh along the Berelekh River, a tributary of the Indigirka River (Fig. 1). The climate of the area (Tumskoy and Schirrmeister 2012) is characterised by a mean annual temperature of $-14.2^{\circ} \mathrm{C}$, a mean July temperature of $+9.7^{\circ} \mathrm{C}$, and a mean January temperature 
Fig. 1 a Location of the study area in NE Siberia; $\mathbf{b}$ location of polygon mire Lhc11 and polygon complex KYT-1 near the research station Kytalyk. Modified after De Klerk et al. (2014)

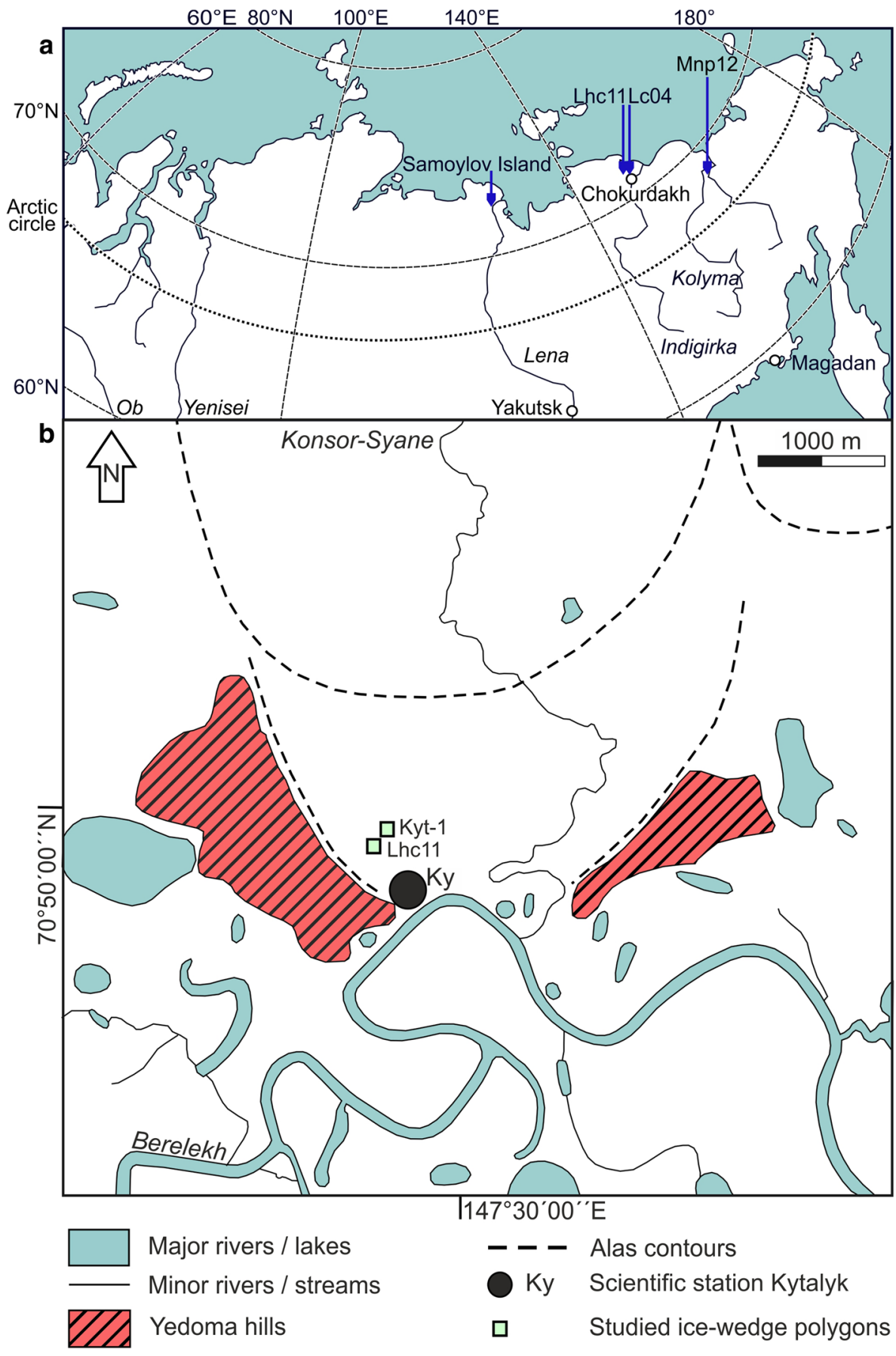

of $-36.6{ }^{\circ} \mathrm{C}$. The permafrost temperature is between -6 and $-4{ }^{\circ} \mathrm{C}$ and total permafrost thickness is estimated to be 200-300 m. Mean annual precipitation is $350 \mathrm{~mm}$.

The Kytalyk landscape (Fig. 1b) includes alluvial landforms near the river, some hills composed of middle to late Pleistocene ice-rich silts and silty sands (yedoma), and several thaw-lake basins resulting from Holocene primary and secondary permafrost thawing (alas basins) (Petrescu et al. 2008; Tumskoy and Schirrmeister 2012; Weiss et al. 2016).
Polygon Lhc11 ( $21 \times 26 \mathrm{~m}$; Fig. 1$)$ is positioned in an alas at a distance of $300 \mathrm{~m}$ to a yedoma ridge and of $600 \mathrm{~m}$ to the bank of Berelekh River. The polygon combines features of low-centre and high-centre polygons and may be a transitional form between both polygon types (Teltewskoi et al. 2012, 2016). A water-filled central depression (unit DE in Fig. 2) is surrounded by ridges (RD and RF), which border on wide troughs (DC and DG), which are probably located over (partly) collapsed ice-wedges. RH and RB (the latter partly collapsed), and DA are ridges and a central depression 
a
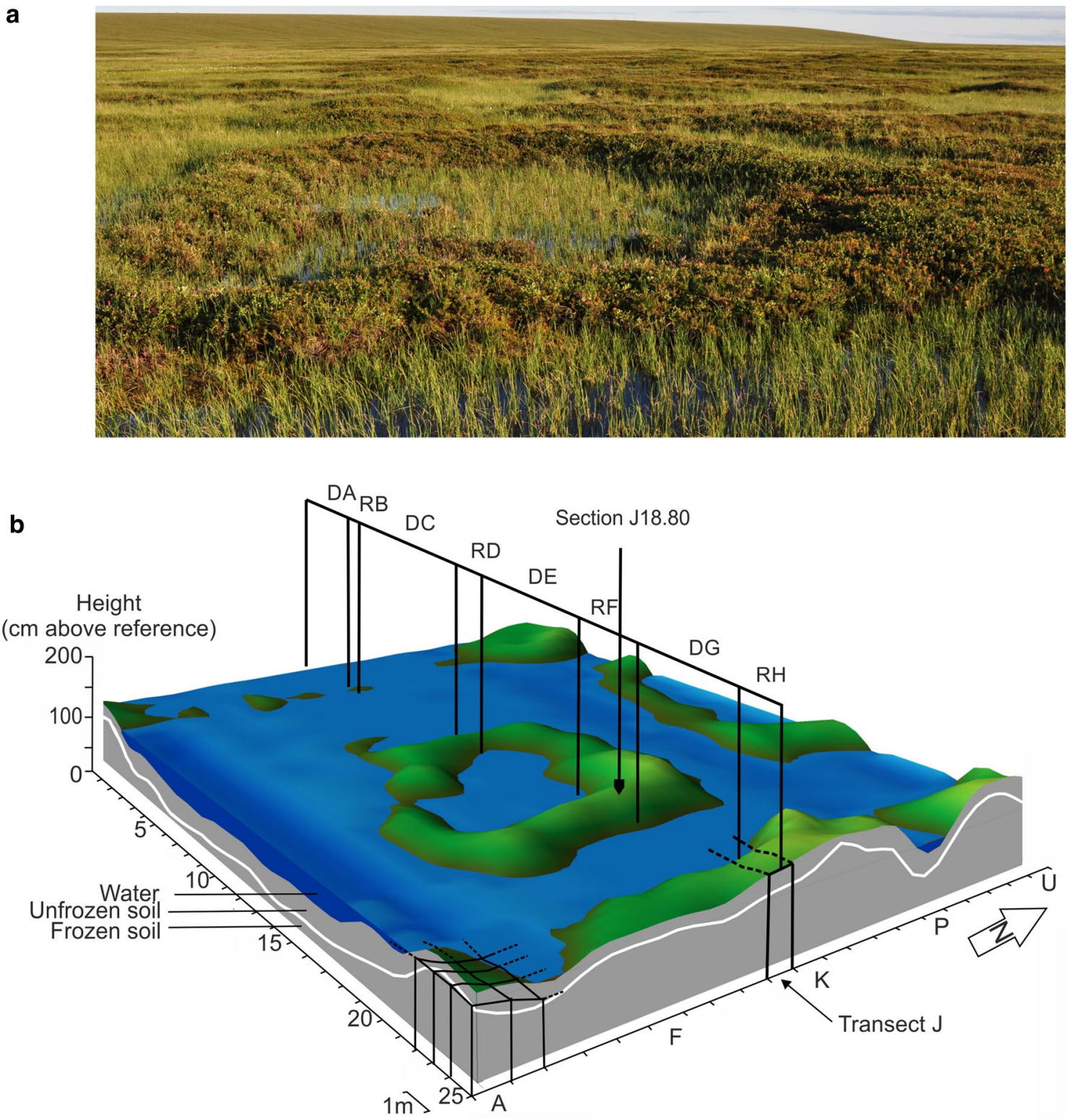

Fig. 2 a Polygon Lhc11 in the field seen from the southeast (photograph by Hans Joosten); b three-dimensional model of polygon Lhc11, with the positions of surface samples transect $J$, peat profile

of adjacent polygons, respectively. Present-day vegetation of the polygon is described by De Klerk et al. (2014). Profile $\mathrm{J} 18.80$ is located in the central part of the major RF-ridge and was studied for various palaeoecological proxies including testate amoebae (Teltewskoi et al. 2016).

A low-centre ice-wedge polygon of study site Kyt-1 (Bobrov et al. 2013) (Fig. 3) lies c. 70 m northeast of Lhc11 and consists of a relatively dry central depression surrounded by ridges.
$\mathrm{J} 18.80$, and designations of the various ridges and troughs/depression. Modified after De Klerk et al. (2014) and Teltewskoi et al. (2016)

\subsection{Research methods}

Polygon Lhc11 was divided into $1 \times 1 \mathrm{~m}$ quadrates with coordinates A-U and 0-25 (Fig. 2). Ground surface elevation, frost table height and open water level were determined in the centre of each plot relative to a horizontal reference level (Teltewskoi et al. 2012). A three-dimensional model of the polygon was prepared with the computer program surfer 11 and modified with the CorelDraw X8 graphical software (Fig. 2).

Surface samples were taken from the centre of each plot along transect $\mathrm{J}$ by collecting moss samples (both green and 


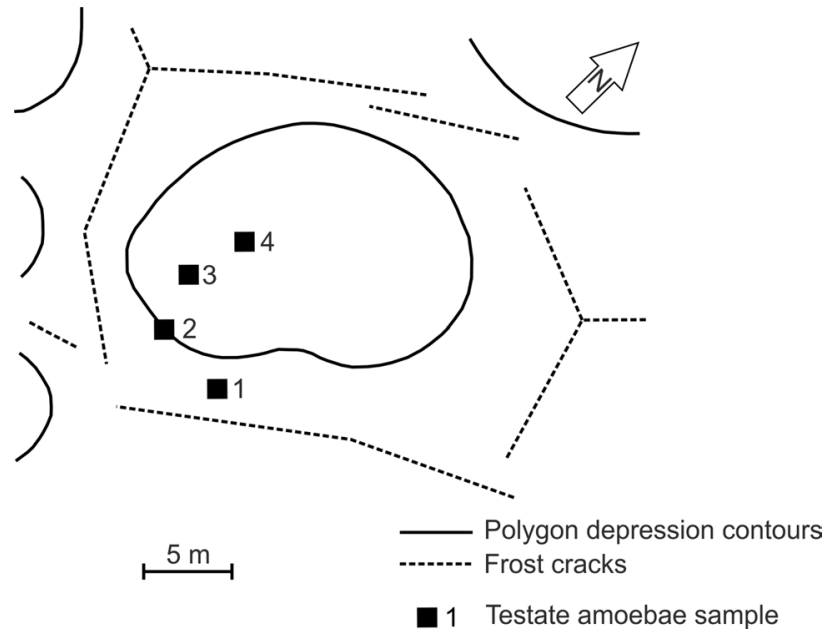

Fig. 3 Site KYT-1 with the location of the surface samples used for testate amoebae analysis. Modified after Bobrov et al. (2013)

brown moss parts) or in their absence surficial litter from an area of around $10 \mathrm{~cm}$ diameter, and stored in plastic bags in a cool room $\left(4{ }^{\circ} \mathrm{C}\right)$ until analysis. Separate subsamples were taken from the mother sample for testate amoebae analysis (this study), C/N determination, and pollen analysis (De Klerk et al. 2014). Samples were taken non-volumetrically because volumes of different material (living and dead mosses of different species, litter)—with their indeterminable time content-make expressing quantities in concentration values or accumulation rates senseless or impossible (Mulder and Janssen 1998, 1999; Räsänen et al. 2004).

Preparation of testate amoebae samples followed the standard Moscow preparation method (Bobrov et al. 2009, 2013) and included addition of water, mixing, sieving $(500 \mu \mathrm{m})$, centrifuging, homogenisation, and addition of glycerol. All analysis was with a Biological Zeiss Axioplan 2 light microscope with magnifications of 100, 200 and 400 times. Nomenclature of testate amoebae follows taxonomical/morphological literature (Table 1), except for C. ecornis f. A (major), which in our material deviates from the typical species by having tests exceeding $300 \mu \mathrm{m}$ in size. We use the names exactly as in the quoted references to secure an unambiguous link with published morphology (Joosten and De Klerk 2002), implying that the meaning of 'form' (f) and 'variety' ( $v$ or var) may differ depending on the reference in which the rank indication is used. 'Taxonomic' names as well as the words 'taxon' or 'taxa' are in this paper used only in a morphological sense ('morphotaxa') without any phylogenetic intent (see Lingafelter and Nearns 2013; Kosakyan et al. 2016). Values are expressed as percentages of all counted specimens in case of samples with more than 70 counted individuals, and as absolute numbers of specimens in case of lower counts (Fig. 4). Ecological interpretation is based on numerous literature sources (Table 1) and distinguishes between aquatic settings, peatmoss, other mosses, and dry soils (i.e. the 'classical' testate amoebae habitats of Chardez 1965). With respect to Sphagnum and other moss habitats we indicated-as far as inferable from the sources-whether the taxon is described in the literature (which mainly relates to temperate regions) for wet (e.g. submerged mosses) or dry peatland habitats (e.g. peatland hummocks), which would in our study area translate to polygon depressions/troughs, and polygon ridges, respectively.

$\mathrm{C} / \mathrm{N}$ ratios were determined by drying the samples at $70-80{ }^{\circ} \mathrm{C}$ for $24 \mathrm{~h}$, grounding in a mill (Pulverisette 14 , Fritsch, Idar-Oberstein, meshes $0.2 \mathrm{~mm}$ ), oven-drying at 80 ${ }^{\circ} \mathrm{C}$ for $2 \mathrm{~h}$ and analysing with a dry combustion $\mathrm{C}$ and $\mathrm{N}$ analyser (Vario-EL, elementar/Hanau, WLF-Detektor).

Data analysis of the surface samples from transect $\mathbf{J}$ included non-metric multidimensional scaling (NMDS). In order to detect whether observed patterns are robust or relate to rare taxa, NMDS was performed (1) on all taxa, (2) on taxa occurring at three or more plots, and (3) on taxa occurring at five or more plots (Figs. 5, 6). Calculations were carried out in R using the metaMDS function of the 'vegan' package, with Bray-Curtis as the default dissimilarity measure (Oksanen et al. 2016). We furthermore explored the influence of environmental parameters (ground surface height, top frozen soil, thickness unfrozen soil, and $\mathrm{C} / \mathrm{N}$ ) on the testate amoebae population with the envfit function from the 'vegan' package, which plots the environmental factors in the ordination scatterplots. Abbreviations for the testate amoebae taxa used in the scatterplots are explained in Table 1.

Processing of palynological samples is described by De Klerk et al. (2014). Values of testate amoebae found in these samples were calculated relative to a sum of pollen grains attributed to Alnus, Artemisia and Pinus. Identification and nomenclature of the testate amoebae found in the pollen samples are after Charman et al. (2000) with Amphitrema flavum renamed to Archerella flavum. In the pollen samples, four different morphological types of Assulina mиscorum tests were distinguished after Schönborn and Peschke (1990). Type 1 and Type 2 have their largest width at around $1 / 3$ distance from the top to the bottom, but a narrow vs. a broad test, respectively. Type 3 and type 4 have their largest width in the centre of the shell, with Type 3 having a conspicuously tapering lower test part, whereas Type 4 does not have such tapering at the bottom (De Klerk et al. 2014).

Nomenclature of mosses follows Ignatov et al. (2006).

\section{Results}

Clear differences can be observed between testate amoebae communities on the dry ridges and in the wet troughs/ depression (Fig. 4). The ridges are characterised by taxa 
Table 1 Taxonomy and ecology of the observed testate amoebae taxa according to scientific literature

\begin{tabular}{|c|c|c|c|c|c|c|}
\hline \multirow[t]{2}{*}{ Taxon (nomenclature after) (abbr. in Fig. 6) } & \multicolumn{6}{|l|}{ Habitat } \\
\hline & water/sapropel & Sphagnum & Other mosses & (wet moss) & (dry moss) & dry soil \\
\hline Archerella flavum (i) (af) & & $\mathrm{x}$ & & $\mathrm{x}$ & & \\
\hline Arcella arenaria (i) (f) & $\mathrm{x}$ & $\mathrm{x}$ & $\mathrm{x}$ & & $\mathrm{x}$ & $\mathrm{x}$ \\
\hline A. arenaria compressa (i) (aac) & & $\mathrm{x}$ & $\mathrm{x}$ & & & $\mathrm{x}$ \\
\hline A. intermedia (i) (ai) & & $\mathrm{x}$ & $\mathrm{x}$ & & & \\
\hline A. ovaliformis (g) (ao) & & & $\mathrm{x}$ & $\mathrm{x}$ & & \\
\hline Assulina muscorum (i) (am) & & $\mathrm{x}$ & $\mathrm{x}$ & & $\mathrm{x}$ & $\mathrm{x}$ \\
\hline A. seminulum (i) (as) & & $\mathrm{x}$ & $\mathrm{x}$ & $\mathrm{x}$ & $\mathrm{x}$ & \\
\hline Centropyxis aerophila (i) (ca) & $\mathrm{x}$ & $\mathrm{x}$ & $\mathrm{x}$ & $\mathrm{x}$ & $\mathrm{x}$ & $\mathrm{x}$ \\
\hline C. constricta (i) (cco) & $\mathrm{x}$ & $\mathrm{x}$ & $\mathrm{x}$ & $\mathrm{x}$ & & $\mathrm{x}$ \\
\hline C. gibba (i) (cg) & $\mathrm{x}$ & $\mathrm{x}$ & $\mathrm{x}$ & & & \\
\hline C. pontigulasiaformis (f) (cp) & $\mathrm{x}$ & & $\mathrm{x}$ & $\mathrm{x}$ & & \\
\hline C. sylvatica (i) (cs) & $\mathrm{x}$ & $\mathrm{x}$ & $\mathrm{x}$ & & & $\mathrm{x}$ \\
\hline Corythion dubium (i) (cdu) & $\mathrm{x}$ & $\mathrm{x}$ & $\mathrm{x}$ & & $\mathrm{x}$ & $\mathrm{x}$ \\
\hline C. dubium minima (i) (cdum) & $\mathrm{x}$ & $\mathrm{x}$ & $\mathrm{x}$ & & & \\
\hline C. orbicularis (i) (co) & $\mathrm{x}$ & $\mathrm{x}$ & $\mathrm{x}$ & & & \\
\hline Cryptodifflugia bassini (i) (cb) & & $\mathrm{x}$ & & & & \\
\hline C. oviformis f. fusca (a) (covf) & $\mathrm{x}$ & $\mathrm{x}$ & $\mathrm{x}$ & & & $\mathrm{x}$ \\
\hline Cyclopyxis eurystoma (i) (ceu) & $\mathrm{x}$ & $\mathrm{x}$ & $\mathrm{x}$ & & & $\mathrm{x}$ \\
\hline C. eurystoma var. parvula (d) (ceup) & & & $\mathrm{x}$ & & & $\mathrm{x}$ \\
\hline Difflugia globulus $(\mathrm{j})(\mathrm{dg})$ & $\mathrm{x}$ & $\mathrm{x}$ & $\mathrm{x}$ & & & $\mathrm{x}$ \\
\hline D. microstoma (i) (dm) & $\mathrm{x}$ & & & & & \\
\hline D. minuta (i) (dmi) & $\mathrm{x}$ & $\mathrm{x}$ & $\mathrm{x}$ & & & \\
\hline Euglypha anodonta (i) (ea) & $\mathrm{x}$ & & & & & $\mathrm{x}$ \\
\hline E. ciliata glabra (i) (ecg) & $\mathrm{x}$ & $\mathrm{x}$ & $\mathrm{x}$ & & & $\mathrm{x}$ \\
\hline E. compressa (i) (eco) & $\mathrm{x}$ & $\mathrm{x}$ & $\mathrm{x}$ & $\mathrm{x}$ & $\mathrm{x}$ & $\mathrm{x}$ \\
\hline E. cristata (i) (ecr) & & $\mathrm{x}$ & $\mathrm{x}$ & & & \\
\hline E. laevis (i) (el) & $\mathrm{x}$ & $\mathrm{x}$ & $\mathrm{x}$ & & $\mathrm{x}$ & $\mathrm{x}$ \\
\hline E. strigosa (i) (es) & $\mathrm{x}$ & $\mathrm{x}$ & $\mathrm{x}$ & $\mathrm{x}$ & $\mathrm{x}$ & $\mathrm{x}$ \\
\hline E. strigosa glabra (i) (esg) & $\mathrm{x}$ & $\mathrm{x}$ & $\mathrm{x}$ & $\mathrm{x}$ & $\mathrm{x}$ & $\mathrm{x}$ \\
\hline E. tuberculata (i) (et) & $\mathrm{x}$ & $\mathrm{x}$ & $\mathrm{x}$ & $\mathrm{x}$ & $\mathrm{x}$ & $\mathrm{x}$ \\
\hline E. tuberculata minor (i) (etm) & $\mathrm{x}$ & $\mathrm{x}$ & $\mathrm{x}$ & $\mathrm{x}$ & & $\mathrm{x}$ \\
\hline Heleopera petricola (i) (hpe) & $\mathrm{x}$ & $\mathrm{x}$ & $\mathrm{x}$ & $\mathrm{x}$ & & $\mathrm{x}$ \\
\hline Hyalosphenia papilio (i) (hpa) & & $\mathrm{x}$ & & $\mathrm{x}$ & & \\
\hline Lesquereusia epistomium (i) (le) & $\mathrm{x}$ & $\mathrm{x}$ & $\mathrm{x}$ & & & \\
\hline Nebela (Argynnia) dentistoma (i) (nd) & $\mathrm{x}$ & $\mathrm{x}$ & $\mathrm{x}$ & $\mathrm{x}$ & & \\
\hline N. lageniformis (i) (nl) & $\mathrm{x}$ & $\mathrm{x}$ & $\mathrm{x}$ & $\mathrm{x}$ & $\mathrm{x}$ & $\mathrm{x}$ \\
\hline N. militaris (i) (nm) & $\mathrm{x}$ & $\mathrm{x}$ & $\mathrm{x}$ & $\mathrm{x}$ & $\mathrm{x}$ & $\mathrm{x}$ \\
\hline N. tincta (i) (nt) & $\mathrm{x}$ & $\mathrm{x}$ & $\mathrm{x}$ & $\mathrm{x}$ & $\mathrm{x}$ & $\mathrm{x}$ \\
\hline Placocista lens (i) (pl) & $\mathrm{x}$ & $\mathrm{x}$ & & & & \\
\hline P. spinosa (i) (ps) & & $\mathrm{x}$ & $\mathrm{x}$ & $\mathrm{x}$ & & \\
\hline Pseudodifflugia gracilis var. terricola (b) (pgt) & & & & & & $\mathrm{x}$ \\
\hline Pyxidicula sp. (py) & $\mathrm{x}$ & $\mathrm{x}$ & $\mathrm{x}$ & & & \\
\hline Schoenbornia humicola $(\mathrm{h})(\mathrm{sh})$ & & & & & & $\mathrm{x}$ \\
\hline S. viscicula (c) (sv) & & & & & & $\mathrm{x}$ \\
\hline Sphenoderia fissirostris (i) (sf) & & $\mathrm{x}$ & $\mathrm{x}$ & & & \\
\hline Tracheleocorythion pulchellum (i) (tp) & & $\mathrm{x}$ & $\mathrm{x}$ & & & \\
\hline Trigonopyxis arcula (i) (ta) & & $\mathrm{x}$ & $\mathrm{x}$ & $\mathrm{x}$ & $\mathrm{x}$ & $\mathrm{x}$ \\
\hline Trinema lineare $(\mathrm{i})(\mathrm{tl})$ & $\mathrm{x}$ & $\mathrm{x}$ & $\mathrm{x}$ & & $\mathrm{x}$ & $\mathrm{x}$ \\
\hline
\end{tabular}


Table 1 (continued)

\begin{tabular}{llllll}
\hline Taxon (nomenclature after) (abbr. in Fig. 6) & Habitat & & & \\
\cline { 2 - 5 } & water/sapropel & Sphagnum & Other mosses & (wet moss) & (dry moss) \\
\hline T. lineare var. minuscula (e) (tlm) & $\mathrm{x}$ & $\mathrm{x}$ & $\mathrm{x}$ \\
Valkanovia elegans (11) (ve) & & & $\mathrm{x}$ \\
Wailesella eboracensis (i) (we) & & $\mathrm{x}$ & $\mathrm{x}$ & \\
\hline
\end{tabular}

Taxonomy follows a: Penard (1890); b: Bonnet and Thomas (1960); c: Schönborn (1964); d: Decloitre (1977); e: Decloitre (1981); f: Beyens and Chardez (1986); g: Chardez and Beyens (1987); h: Schönborn et al. (1987); i: Mazei and Tsyganov (2006); and j: Lorencová (2009). Ecology is after Penard (1890), Hoogenraad and De Groot (1940), De Graaf (1956), Bonnet and Thomas (1960), Decloitre (1962), Grospietsch (1964, 1972), Schönborn (1964), Chardez (1965), Schönborn (1966), Decloitre (1977), (1981), Beyens and Chardez (1986, 1995), Beyens et al. (1986a, 1990), Chardez and Beyens (1987), Rauenbusch (1987), Schönborn et al. (1987), Charman et al. (2000), Bobrov et al. (2002, 2004, 2009), Mazei and Tsyganov (2006), Andreev et al. (2008), Lorencová (2009), and Müller et al. (2009). The abbreviations after the taxon names are those as used for the NMDS analysis (Fig. 6)

typical for dry peatland habitats (Table 1), including Assulina muscorum (all ridges), Valkanovia elegans (ridge $\mathrm{RD})$, Schoenbornia viscicula (RD and RF), Trigonopyxis arcula (RH), Cyclopyxis eurystoma var. parvula (RF), and S. humicola (RH). Furthermore, the ridge communities include many taxa that are known from both wet and dry habitats and, thus, are hydrologically indifferent, e.g. Trinema lineare (all ridges), Nebela tincta (all ridges except RF), Centropyxis aerophila (RB), Placocista spinosa (RB), Nebela parvula (RB, RD), Hyalosphenia papilio (RB), Arcella arenaria (RB), Centropyxis sylvatica (RB), Heleopera petricola (RB), Euglypha laevis (RD, $\mathrm{RF}, \mathrm{RH})$, E. compressa (RD, RH), Arcella arenaria compressa (RD), Euglypha anodonta (RD), E. strigosa (RD), Corythion orbicularis $(\mathrm{RD}), C$. dubium minima $(\mathrm{RD})$ and C. dubium (RD, RF, RH), Cyclopyxis eurystoma (RH), Nebela militaris $(\mathrm{RH})$ and $N$. tincta $(\mathrm{RH})$. Taxa of which we found only few ecological descriptions in the literature and of which the full hydrological width may still be unknown include Arcella ovaliformis (RB), Cryptodifflugia ovivormis f. fusca (RB), Nebela (Argynnia) dentistoma (RB), Centropyxis pontigulasiaformis (RD), and Wailesella eboracensis (RH) (Table 1). Archerella flavum, a species known from wet Sphagnum habitats (Table 1), occurs on ridges $\mathrm{RB}$ and $\mathrm{RH}$.

The troughs and depression contain various taxa that are exclusively described for aquatic environments or wet moss habitats, including Difflugia globulus (DA, DG), D. microstoma (DC), and Hyalosphenia papilio (DG). These are, however, accompanied by various taxa typical for dry environments, e.g. Valkanovia elegans, Assulina muscorum, Schoenbornia humicola, Cyclopyxis eurystoma var. parvula and Schoenbornia viscicula. Especially prominent in trough DG are Trinema lineare var. minuscula and Cryptodifflugia ovivormis f. fusca, whose full ecological ranges are still not fully clear, but which occur with $80 \%$ and $40 \%$, respectively.
All other taxa observed in the low-lying elements are known from both dry and wet habitats.

Four surface samples from drier and humid parts of the nearby polygon Kyt-1 (Bobrov et al. 2013) show mainly taxa with broad hydrological preferences (Fig. 4), e.g. Cyclopyxis eurystoma, Trinema lineare, Euglypha laevis, Nebela tincta and Corythion dubium. Assulina muscorum is the only taxon in Kyt-1 exclusively known from rather dry habitats. No taxa were found that are known from wet habitats only.

The surface samples of polygon Lhc11 did not only include empty tests but living specimens and cysts as well (although only in small portions and therefore not separately included in Fig. 4).

Testate amoebae identified in the palynological samples (Fig. 4; cf. De Klerk et al. 2014) include Arcella types that are dominant on the northwestern ridge $\mathrm{RB}$, and various Assulina muscorum types that are prominent on the other ridges (RD, RF and RH). Archerella flavum was found only incidentally, except in sample 20 in depression DG where it occurred with high values. Surprisingly, Archerella was not found in the palynological sample of plot J24 where it was observed abundantly in the testate amoebae sample.

$\mathrm{C} / \mathrm{N}$ values are low in the samples from the depression and troughs with values around 20, whereas values are considerable higher up to 60 on the drier ridges (Fig. 4). Of the mosses found along the transect, Sphagnum flexuosum and S. squarrosum occur prominently on the slightly submerged ridge $\mathrm{RB}$ and in through $\mathrm{DG}$, with minor occurrences in trough DC and on ridge RD. Hypnum sp., Dicranum groenlandicum, D. acutifolium and Aulacomnium palustre occur in low amounts mainly on ridges RD, RF and RH.

Sample scores from NMDS axis 1 are in all three versions-i.e. including all taxa, only taxa occurring in at least three plots, or only taxa occurring in at least five plotsmostly low along the depressions and high along the ridges (Fig. 5). An exception to this pattern is the central depression DE, where positive sample scores on NMDS axis 1 


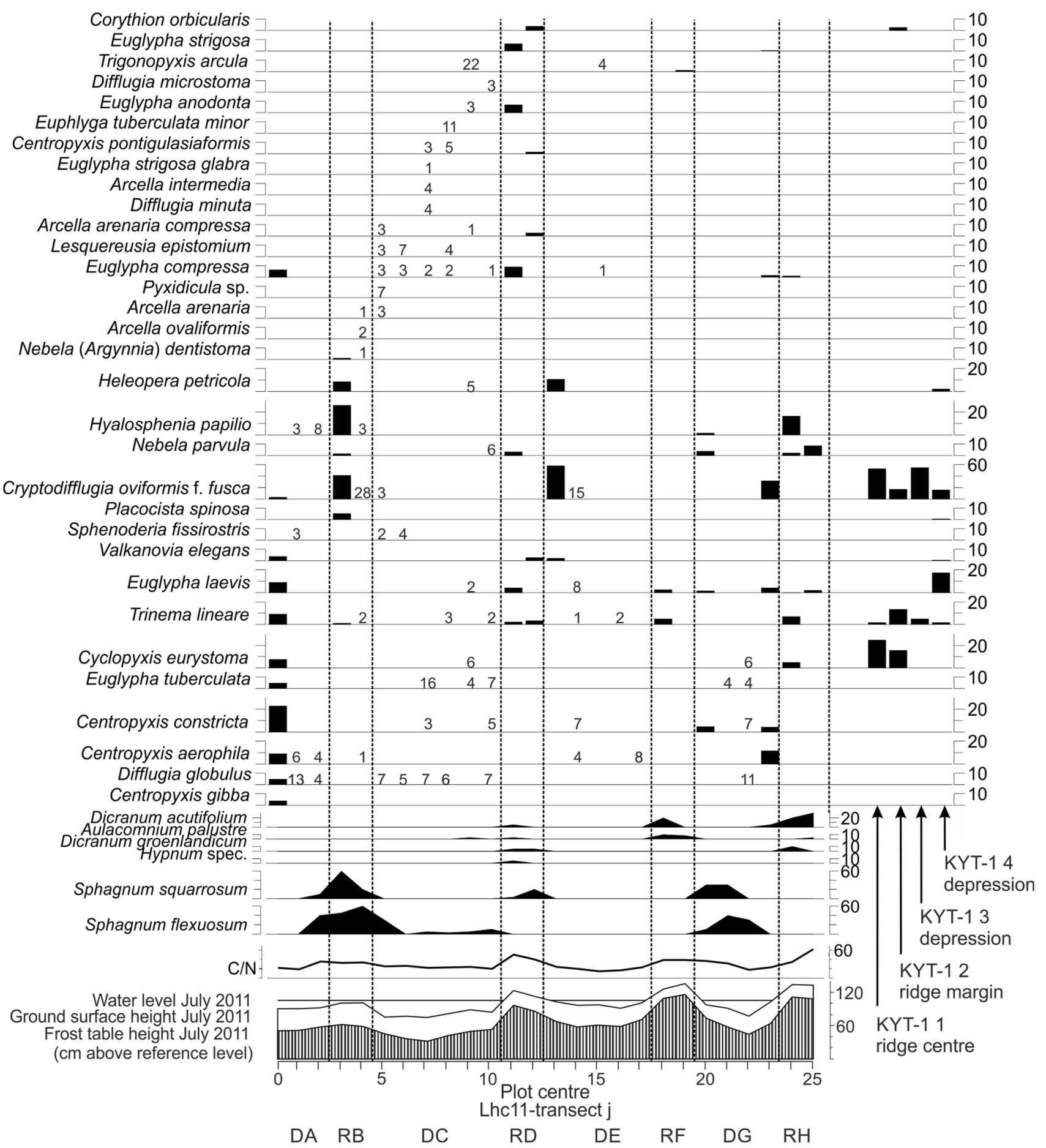

Fig. 4 Testate amoebae from surface samples of Lhc11-transect J and KYT-1. Percentages of samples with more than 70 individuals are presented as black bars, of samples with a lower number of individuals absolute counts are presented. Also indicated is ground surface

suggest greater similarity with the ridge samples. However, the positive scores on NMDS axis 1 may be an artefact caused by the low number of taxa and specimens observed in depression DE. Sample scores on NMDS axis 2 are mostly contour, moss species along the transect, $\mathrm{C} / \mathrm{N}$ ratio, and testate amoebae types found in the palynological samples of transect $\mathbf{J}$ (from De Klerk et al. 2014)

negative between sample 0 and 8 and in samples 16 and 17, and mostly positive in the other samples (Fig. 5). The samples with negative values are characterised by the absence 


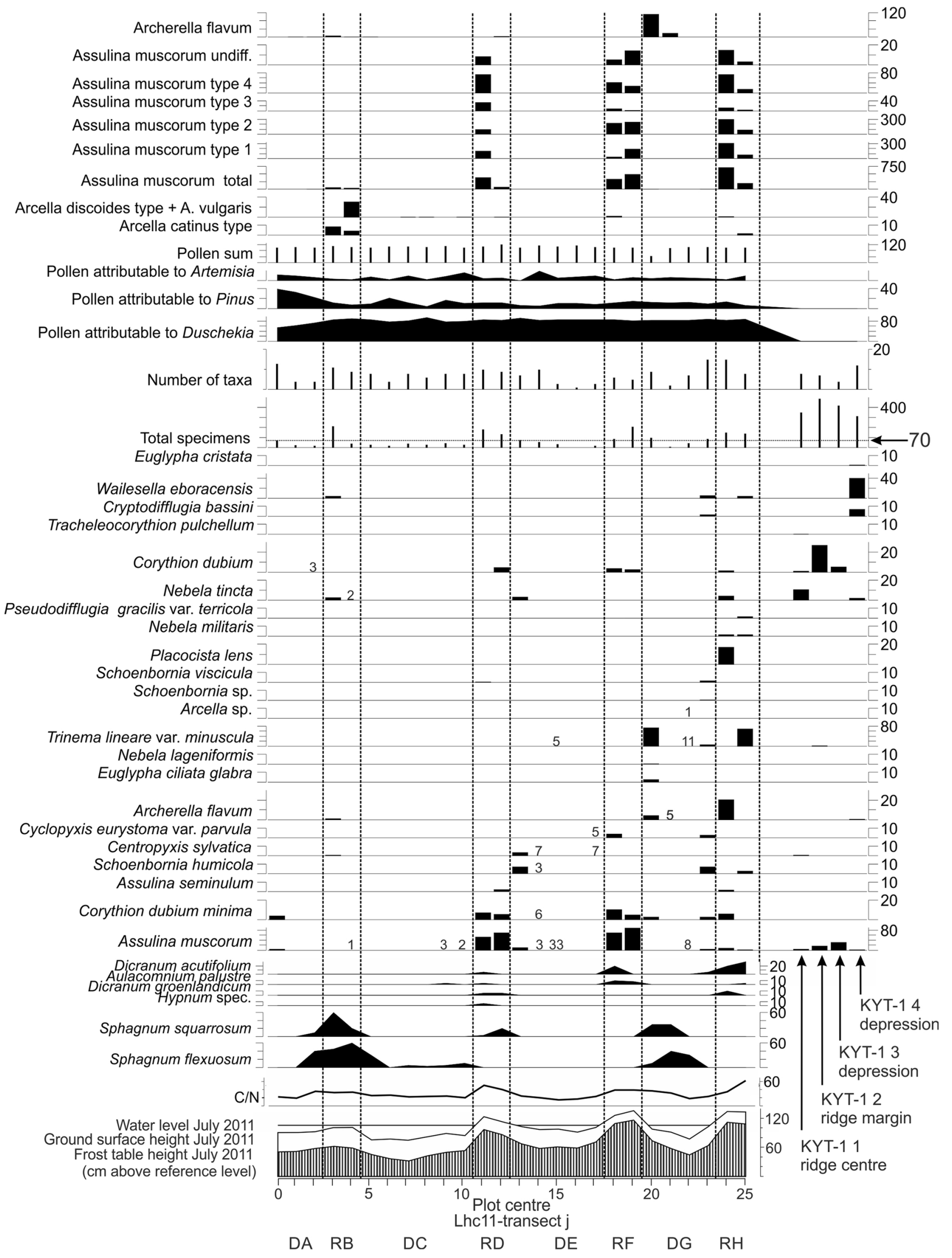

Fig. 4 (continued) 


\section{NMDS axis 1}

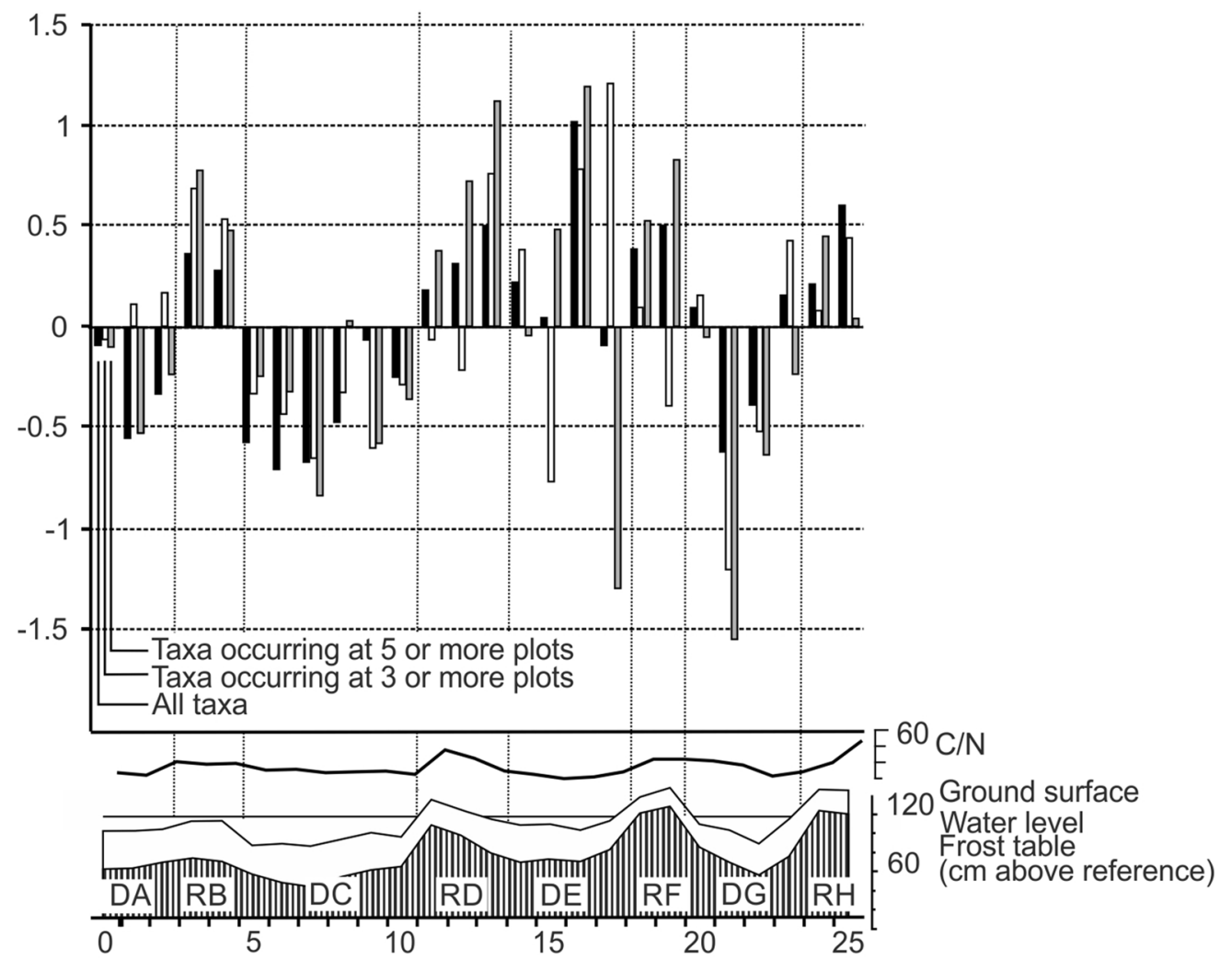

NMDS axis 2

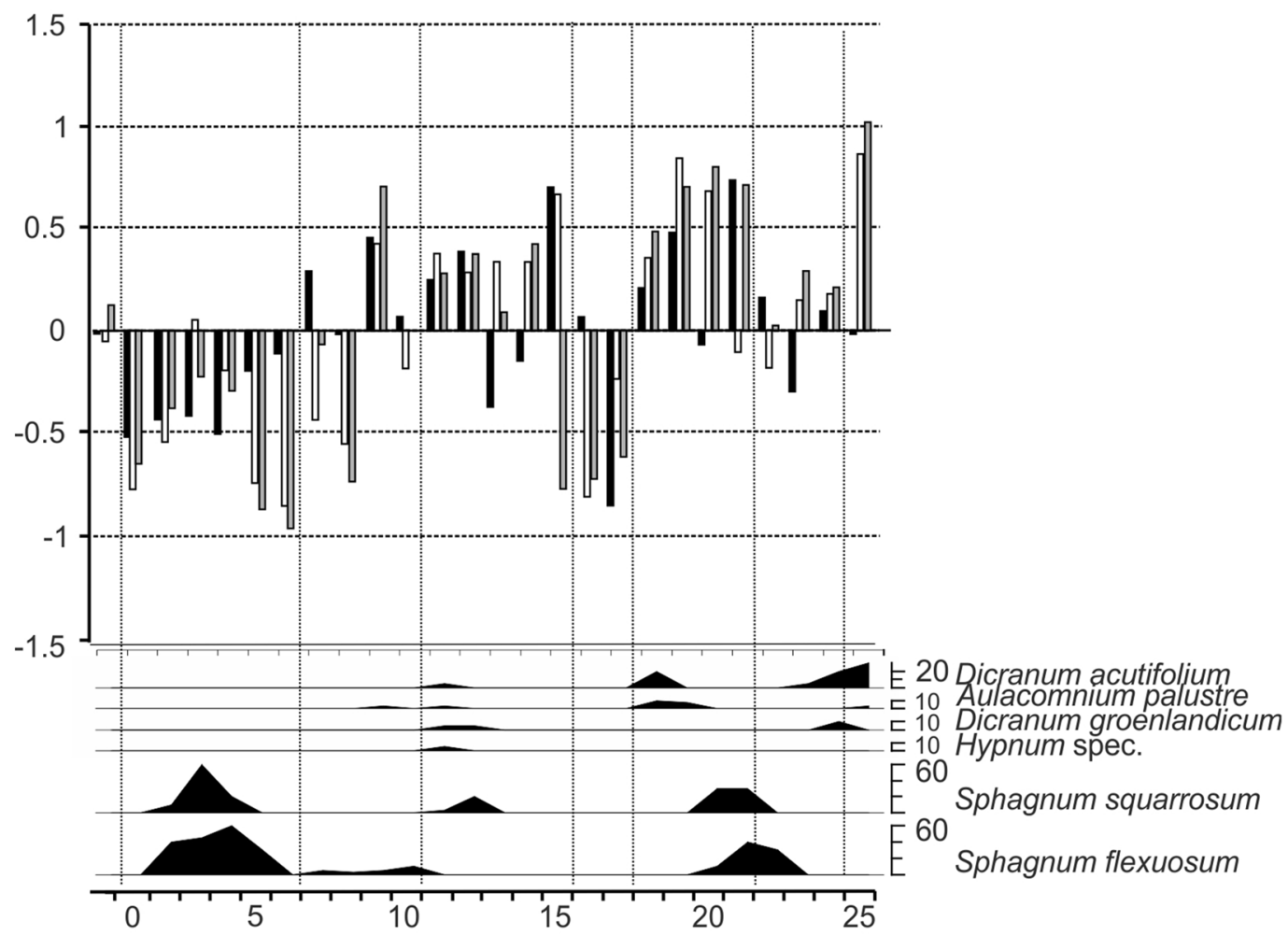

Fig. 5 Samples scores of non-metric multidimensional scaling (NMDS) of axes 1 and 2 
Fig. 6 Taxa scores and samples scores of non-metric multidimensional scaling along the first and second axes. The arrows represent the environmental parameters (US: Unfrozen soil; FTH: Frost table height, GSH: Ground surface height). For the abbreviations of the taxa see Table 1; the lines connect adjacent samples on the polygon ridges

of the overall most abundant taxa, i.e. Assulina muscorum and Trinema lineare var. minuscula.

The biplots (Fig. 6) show that of the taxa with more than five occurrences, Euglypha tuberculata (et) and Centropyxis aerophila (ca) have similar scores as the depression samples, whereas Assulina muscorum (am), Centropyxis dubium minima (cdum), Corythion dubium (cdu), Cryptodifflugia oviformis f. fusca (covf), Hyalosphenia papilio (hpa) and Valkanovia elegans (ve) are most closely related to the ridges.

\section{Discussion}

\section{Ecology}

Multivariate analysis demonstrates that testate amoebae distribution across the polygon is not uniform but determined by microtopography and related factors. The NMDS analysis shows that the dry ridges are populated by taxa that are known from dry habitats only or that are hydrologically indifferent (Figs. 5, 6).

In the wet troughs and depression-apart from hydrologically indifferent species-various wet-living taxa occur together with taxa of typically dry environments. Such cooccurrence has also been observed by Mitchell et al. (2008), Booth (2008), Bobrov et al. (2009, 2013), Tsyganov et al. (2012a) and Teltewskoi et al. (2016). Testate amoebae may survive longer periods of unfavourable conditions as cysts (Mediola et al. 1990; Charman et al. 2000; Charman 2001), and it is well conceivable that in ice-wedge polygons a spring snowmelt results in a wet setting with wet-living taxa that is followed by a dry environment with dry-living testate amoebae when water levels drop later in the year. This corresponds well to the fact that different taxa have different seasonal optima for reproduction (Mazei and Tsyganov 2007/2008; Lamentowicz et al. 2013): population structure at identical spots may differ greatly between points in time only a few months apart (Marcisz et al. 2014). Testate amoebae are short-living (Charman et al. 2000; Charman 2001; Clarke 2003) and react to environmental changes immediately (Charman et al. 2000; Payne 2012, 2013) or with short lags (Beyens et al. 2009). Since surface samples generally encompass several years (Bradshaw 1981; Räsänen et al. 2004; De Klerk et al. 2009), the surface samples of Lhc11 may very well reflect a seasonal mix of testate amoebae taxa. Such dry/wet pulses are too short to induce a change

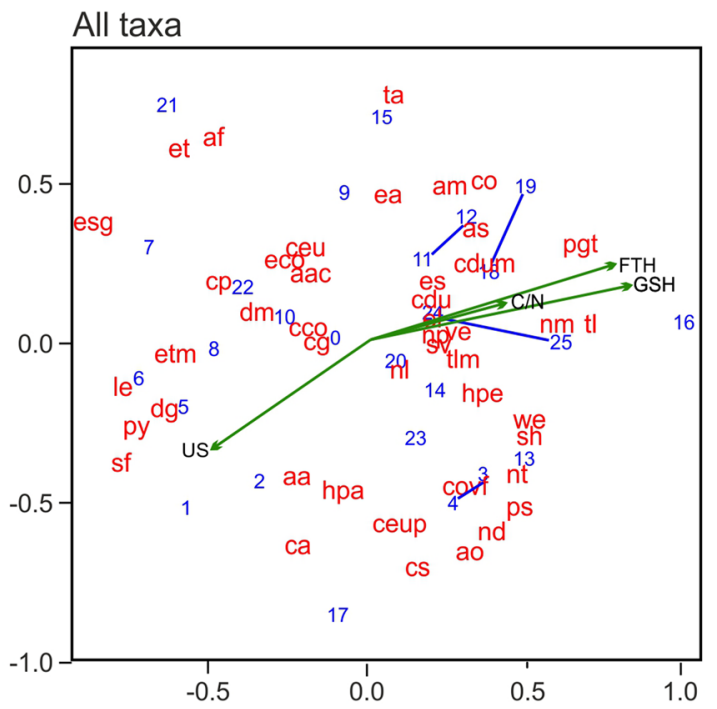

Taxa occurring at 3 or more plots

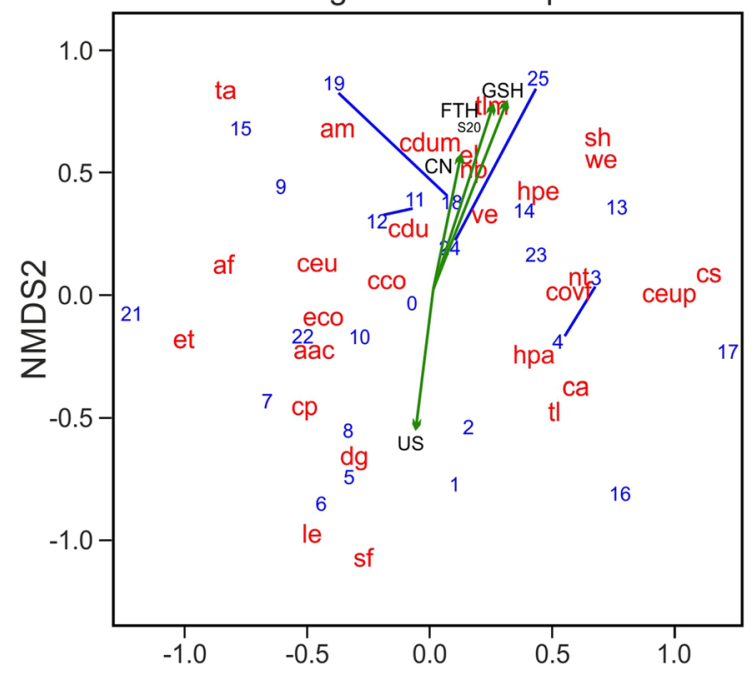

Taxa occurring at 5 or more plots

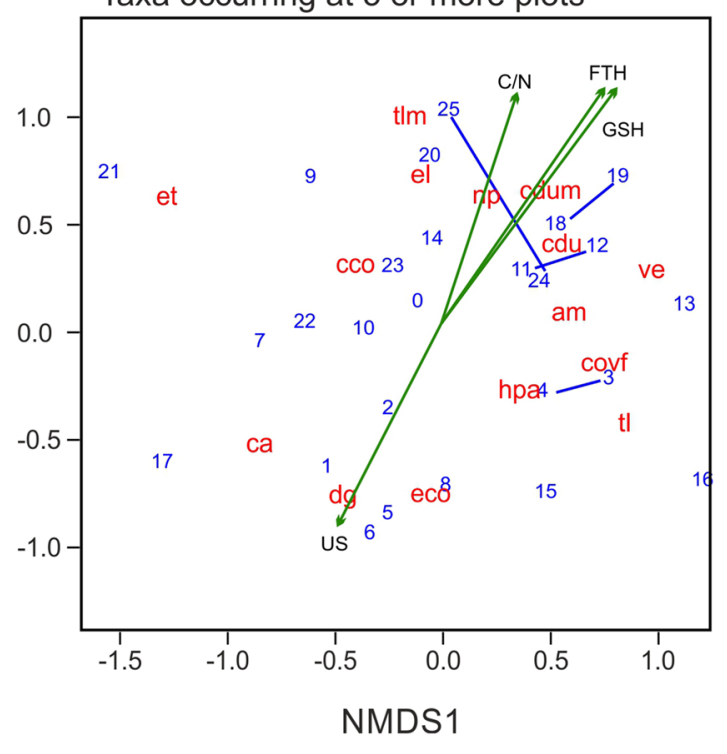


in local plant community, and pollen/macrofossil diagrams from fossil peat sections will therefore display essentially long-term dry or wet phases without registering seasonal changes. This effect is clearly discernible in the palaeoecological data of peat profile J18.80 (Teltewskoi et al. 2016). The co-occurrence of typically wet, dry and indifferent taxa may explain why the low-lying settings show larger variation in the NMDS (Figs. 5, 6). The depression DE shows in the NMDS a greater similarity to the ridges than to the other wet settings, which may relate to the more shallow character of this depression compared to the troughs.

This observation implies that the dry ridges of the studied polygon - of which the surface samples do not include typically wet taxa-have never been subject to flooding, whereas the troughs and central depression dried out regularly. This is in accordance with observations of Boike et al. (2008) in the Lena Delta, where polygon depressions that are waterfilled in most years may dry-out completely in dry years. The possibility that dry-living testate amoebae have flushed-in into the depressions from the adjacent ridges is not supported by short-distance pollen studies from other ice-wedge polygons (De Klerk et al. 2009, 2014, 2017) where tests of Assulina muscorum were only found on dry ridges and were not found to be displaced laterally into low-lying settings. Also Charman et al. (2000) observed that lateral displacement of testate amoebae hardly occurs. The co-occurrence of wet- and dry-living taxa may, thus, reflect seasonal alternation of hydrological settings.

We conclude that in palaeoecological studies of icewedge polygons testate amoebae are an accurate proxy for past wetness and allow the reconstruction of wet (such as in a polygon depression/through) or dry conditions (such as of a ridge) and of polygon development, including the expansion and collapse of ridges. Teltewskoi et al. (2016) tested the indicative value of various proxies in peat profile $\mathrm{J} 18.80$ from the same polygon Lhc11 (Fig. 2) and found that testate amoebae inferred wetness fitted well with the degree of wetness as reconstructed from other palaeoecological proxies. The inference of seasonal changes in wetness is limited to testate amoebae and not provided by pollen or macrofossil analysis. Our study of merely 30 samples from two polygons in one sample area is admittedly insufficient to cover the entire ecological and biogeographical variation in ice-wedge polygons, but the factors that determine testate amoebae distribution emerge clearly from our data.

The four different Assulina morphotypes distinguished during pollen analysis-derived from the same mother samples as the samples for testate amoebae analysis-have different distribution over the surface samples (Fig. 4; cf. De Klerk et al. 2014). The palynological analysis of peat profile J18.80 also displays a different distribution pattern of the four morphotypes (Teltewskoi et al. 2016). This diverse behaviour indicates that the morphological plasticity of testate amoebae is not a matter of chance but caused by one or more still unknown factors.

We refrained from developing a water table transfer function for the study area. Such transfer functions have been constructed for many regions (Charman and Warner 1997; Payne et al. 2006; Charman et al. 2007; Amesbury et al. 2013; Lamarre et al. 2013; Mitchell et al. 2014; Swindles et al. 2015b, c; Taylor et al. 2019). They can, however, not effectively be applied to our Kytalyk dataset, as water table depth and soil moisture preferences of testate amoebae differ greatly between geographical regions (Charman and Warner 1997; Bobrov et al. 2002; Mitchell et al. 2008) and transfer functions, thus, only have regional significance. Lately attempts have been made to construct supra-regional water table transfer functions (e.g. Amesbury et al. 2016, 2018), but this may be premature at present. A major methodological problem is that water table depths are mostly measured only once during summer when generally low water tables prevail (Payne et al. 2006; Charman et al. 2007; Mitchell et al. 2008; Swindles et al. 2015c), i.e. total annual or seasonal variation is not captured. For Lhc11 two summer water table measurements are available with considerable differences. Over the period July 24th-August 4th 2011, water levels in the polygon varied between 100 and $111 \mathrm{~cm}$ above reference level, whereas at the moment of sampling the water table along transect $\mathrm{J}$ was $105 \mathrm{~cm}$ above reference (cf. Figure 4). Between August 19th and 22th 2011 water levels in the polygon ranged between 98 and $105 \mathrm{~cm}$, with those of transect $\mathrm{J}$ being $100 \mathrm{~cm}$ above reference at the moment of measurement (A. Teltewskoi et al. unpublished data). Such differences within only 1 month, or even 4 days, are considerable compared to the small height differences of polygon microtopography. A further complication is that various amoebae taxa react differently to large water level fluctuations compared to minor fluctuations (Sullivan and Booth 2011), which obscures interpretation when only one (e.g. the mean) water level is used. Last but not least, water table levels are not necessarily a good indicator of soil humidity, water availability and other water-related ecological factors (Price 1997). In (sub-)Arctic peatlands the shallow permafrost and its thawing influence local water availability and soil moisture to the extent that site conditions are incomparable to those of peatlands in non-permafrost areas (Bobrov et al. 2013; Lamarre et al. 2013). This raises the question to what extent phreatic water levels in the 'humid' Arctic with its semi-desert-like precipitation volumes (see Walker et al. 2005, Tchebakova et al. 2009, Chevychelov and Bosikov 2010, Van Huissteden 2020) are a suitable overall proxy for the operational factors (sensu Zonneveld 1995) that determine the presence of species or whether other moisture-related parameters have to be chosen to calibrate sensible transfer functions. Anyway, before reliable water table reconstruction is possible across the NE 
Siberian Arctic, considerably more research is necessary to obtain a dataset of sufficient quality and quantity. Additional to the considerations above, various other methodological problems still have to be solved, especially concerning sample volume, preparation, height of counts and the applied statistical models (cf. Amesbury et al. 2013; Avel and Pensa 2013; Payne et al. 2016; Van Bellen et al. 2017).

Apart from a relation to soil surface height and associated hydrological regimes, also a relation between testate amoebae taxa and $\mathrm{C} / \mathrm{N}$ ratio, as an indicator of trophic conditions in mires (Succow and Stegmann 2001), is conceivable. $\mathrm{C} / \mathrm{N}$ values in polygon Lhc11 conspicuously relate to surface microtopography (cf. Figure 4), which is in accordance with finds from other NE Siberian polygon mires (De Klerk et al. 2009, 2014; Minke et al. 2009). The observed testate amoebae distribution may, thus, not only relate to moisture but also to nutrient availability. Taylor et al. (2019) found electric conductivity as an important explanatory variable of testate amoebae distribution, which they attribute to trophic status. In ice-wedge polygon Lc04 near Chokurdakh (Fig. 1) also a weak relation between testate amoebae and $\mathrm{pH}$ was found (De Klerk et al. 2009), but this variable was not measured in Lhc11.

In the NMDS, the measured environmental factors correlate with the first axis in the calculations with all taxa. This underlines that the distribution of the testate amoebae is primarily ruled by surface elevation and the resulting hydrological conditions. The factor of the unfrozen soil is in opposite direction because its thickness is larger in the depressions than on the ridges. For the scatterplots with taxa that occur in at least three or at least five of the samples, the environmental parameters correlate to axis 2 . This suggests that the occurrence of the most abundant taxa-including Assulina muscorum and Trinema lineare var. minuscula,- - is determined apart from surface elevation also by one or more other, possibly not investigated, factor(s). Conspicuously, the $\mathrm{C} / \mathrm{N}$ is closer to the variable 'top frozen soil' than to 'ground surface height', but the differences are probably too small to be relevant.

\section{Some biogeographical aspects}

Beyens and Bobrov (2016) inventoried a total of 378 different testate amoeba species for the entire Arctic, whereas Bobrov and Wetterich (2012) found 215 different species and subspecies for NE Siberia only. Of the 13 most common taxa in the Arctic (Beyens and Bobrov 2016), i.e. taxa that occur in more than $50 \%$ of all Arctic samples, we found Trinema lineare, Assulina muscorum, Centropyxis aerophila, Corythion dubium, Euglypha laevis. E. strigosa glabra, and Centropyxis sylvatica.

Most testate amoebae taxa in the Siberian Arctic are cosmopolitan and the number of endemic species is limited
(Bobrov and Wetterich 2012). Bobrov and Wetterich (2012) pose that Centropyxis gasparella, C. gasparella v. corniculata, C. pontigulasiformis, Difflugia vanhoornei and Difflugia ovalisima might be restricted to the Arctic. Of these, only $C$. pontigulasiaformis was found in low amounts in the surface samples of polygon Lhc11.

Beyens and Bobrov (2016) distinguished several testate amoebae regions in the Arctic with Kytalyk belonging to the Siberian cluster C1-region. This region is characterised by a larger number of Difflugia and Arcella taxa compared to the other Arctic regions. Beyens and Bobrov (2016) discuss whether this difference may be caused by a sample bias, i.e. by the comparatively large number of analysed aquatic samples from the Siberian region, but reject this hypothesis. In polygon Lhc11, Difflugia and Arcella were only found in depression and troughs, but the latter genus was also found widespread in Arctic Eastern Siberia in surface samples from drier polygon peatland settings (polygons Lc04, Mnp12 and those from Samoylov Island, cf. Figure 1; De Klerk et al. 2009, 2017 and unpublished data).

Archerella flavum has until now only been described from wet Sphagnum habitats (Table 1), but the factor forcing such dependence has not yet been identified (Portsmuth et al. 2011). In surface sample 24 (Fig. 4), where Sphagnum is absent (also from all adjacent plots; De Klerk et al. 2014), the taxon was found in Dicranum groenlandicum and D. acutifolium mosses (Fig. 4), implying that at least in the Kytalyk area A. flavum also occurs in dry, non-peatmoss habitats. The taxon is regularly found in pollen samples from dry ridge settings in the Arctic, e.g. in the ice-wedge polygons Lc04 near Chokurdakh and Mnp12 near Pokhodsk (Fig. 1), be it predominantly in the lower ridge parts anduntil now-always in Sphagnum habitats (De Klerk et al. 2009, 2014, 2017).

The examples of Arcella and Archerella illustrate that in the Artic the 'standard' indicative value of testate amoebae species for water levels should be interpreted with critical awareness of the particular humidity consequences of permafrost conditions.

\section{Height of counts in relation to hydrological settings}

In our study, high testate amoebae counts (between 70 and 300 individuals) were largely restricted to samples from dry ridges. For the samples from the relatively dry polygon Kyt-1 even higher counts (300-400) were achieved. It seems, thus, that dry conditions allow for a better counting of testate amoebae than wet conditions. The absence of a time control for surface samples precludes a conclusion whether these differences reflect different population densities, slower accumulation of matrix material, or differences in test extraction and analysis efficiency between different materials (e.g. mosses versus litter). The countability of 
samples primarily relates to the amount of debris in the sample after preparation (Bobrov et al. 2009). Mosses from drier habitats generally provide 'cleaner' samples, which allow identification of more testate amoebae specimens within a reasonable time, than the samples from wet settings where more residual debris prohibits a clear view.

Whereas for standard testate amoebae analysis a count of at least 150 tests is recommended (Beyens and Meisterfeld 2001; Payne and Mitchell 2009), peat samples often do not allow such high counts within a reasonable time (Charman et al. 2001; Bobrov et al. 2004; Müller et al. 2009; Payne and Pates 2009; Schirrmeister et al. 2011). For various research questions counts of 100 or even 50 tests may be sufficient (Mitchell and Gilbert 2004; Payne and Mitchell 2009; Booth et al. 2010; see also Mosimann 1965, Heiri and Lotter 2001 and Djamali and Cilleros 2020). Indeed, low counts are always better than no counts, but they should be interpreted with sufficient care (Payne and Mitchell 2009). We chose to calculate percentages for counts containing 70 or more tests, which is less robust than the recommended number of 100 or 150 , but provides a statistically more solid calculation basis than 50 .

The numbers reached in testate amoebae analysis are low compared to the much higher pollen sums commonly reached in pollen analysis. The difference is inherent to the methods used. Most testate amoebae do not survive the treatment used for pollen analysis (Hendon and Charman 1997; Charman et al. 2000; Payne et al. 2012), especially acetolysis, which removes and destroys much organic debris. Testate amoebae samples, thus, include (much) more debris, which makes it difficult to see the tests. The lower numbers of tests may not really be problematic as research questions mainly focus on local ecology, which can sufficiently be characterised by few indicative specimens (Birks and Birks 1980).

\section{Possible population change after sampling}

The fact that in the samples cysts and living specimens were found next to empty 'dead' tests shows that after field sampling and storage populations of living testate amoebae may persist for several years. The question arises whether during storage the population structure may have changed. Personal observations of A. Bobrov indicate that samples preserved in dry and cold/frozen conditions do not change significantly in community structure. Also Mazei et al. (2015) found that samples stored for 16 weeks in a refrigerator at $5{ }^{\circ} \mathrm{C}$ did not show detectable changes in population structure. However, more research into this issue is desirable.

\section{Comparison with testate amoebae found in pollen samples}

An important question in palynology is to what extent the few testate amoebae found in pollen samples may substitute for full testate amoebae analysis. Little research has been done on how the taxa and numbers found in pollen samples correspond to those in testate amoebae samples (e.g. Van Leeuwen et al. 2008; Payne et al. 2012). In palynological samples generally only members of the genera Arcella, Assulina and Archerella are found because sample preparation destroys the tests of almost all other taxa (Hendon and Charman 1997; Payne et al. 2012), although incidentally also other taxa are being found (Miola 2012; Payne et al. 2012). Since the samples used for testate amoebae and pollen analysis stem from the same mixed 'mother sample' (De Klerk et al. 2014), the subject can be systematically addressed with our study.

In the testate amoebae diagram of Lhc11 Assulina muscorum has prominent values on ridges RD and RF and less conspicuously on ridge $\mathrm{RH}$, whereas in the pollen diagram this taxon has similar values on all three ridges (although on ridge RD mainly in sample 11). This may relate to the different calculation basis. In the testate amoebae diagram, the Assulina percentage in a sample does only not depend on the abundance of Assulina itself, but also on the abundance of all other taxa in that sample (together constituting 100\%), a non-linearity known as the 'Fagerlind effect' (Fagerlind 1952; Prentice and Webb 1986). Such calculation basis makes it impossible to compare the real population sizes of single species between samples (Fagerlind 1952). In contrast, the Assulina value of a pollen sample is calculated against the sum of selected pollen types, i.e. an external reference, which provides for a value, independent from the abundances of other testate amoebae taxa in the sample, making a direct quantitative comparison impossible.

In the pollen surface samples, test types attributable to Arcella species have been found that are named differently compared to the species found in the testate amoebae samples. This relates to the use of the Charman et al. (2000) key, which has been noted to miss some Arcella taxa/morphs (Beyens and Meisterfeld 2001; Mitchell et al. 2008; Payne et al. 2011). Arcella occurs in the pollen surface samples J3, $\mathrm{J} 18$ and $\mathrm{J} 24$, whereas in none of the parallel testate amoebae samples the genus was found. Although care was taken to produce a largely homogeneous sample, the subsamples for pollen and testate amoebae analysis may stem from different parts of the sample (maximally $10 \mathrm{~cm}$ apart). Mitchell et al. (2000) and A. Bobrov (personal observations) found that testate amoebae assemblages may differ considerably over even a few $\mathrm{cm}$ distance. The same effect may apply to Archerella flavum, which occurs prominently in testate amoebae sample $\mathrm{J} 24$, whereas it is absent from the corresponding pollen 
sample. Also Payne et al. (2012) found distributional differences between parallel testate amoebae and pollen samples but refrain from mentioning the horizontal distance between the samples.

\section{Concluding remarks}

Testate amoebae analysis is a valuable tool for studying Arctic peatlands. Especially the polygon ridges contain clear and distinct testate amoebae populations that allow a palaeoecological inference of dry phases in peat profiles. The ability to survive unfavourable conditions as cysts implies that sites with regular (seasonally) changing hydrology may leave in one sample a distinct signal of taxa belonging to different soil moisture conditions, which allows the recognition of short-term moisture changes not inferable from other palaeoecological proxies. Population differences over only short $(\mathrm{cm})$ horizontal distances may, however, hamper an unambiguous interpretation, whereas also the only low possible counts of wet polygon settings hamper a full ecological inference.

In cases where only a limited number of testate amoebae specimens is found and a full ecological inference is hindered, the ecological significance of single taxa still provides valuable information on local ecology without any knowledge of the total population structure. In the case of occurrence of taxa/morphs from different habitats, the conclusion of micro-distance variety or short-term variation can be drawn.

Although it may provide valuable information, the counting of testate amoebae in pollen samples is by no means an alternative to complete testate amoebae analysis.

The present study reflects-with a limited number of samples - only a small selection of the total testate amoebae population diversity in NE Siberian polygon mires, but it provides accurate insights in the hydrological processes at work. This is significant for understanding the population dynamics that apply to other testate amoebae taxa as well. Future research including short-distance sampling from various polygons with different settings can be expected to reveal further information. It will add to the great progress that has been made over the last decade and will further increase the importance of testate amoebae analysis as a (palaeo)ecological discipline for (sub-)Arctic regions and beyond.

Acknowledgements Richard Payne (1978-2019) died tragically during a mountain-climbing accident in the summer of 2019 shortly after we had submitted our manuscript for which we had named him as a potential reviewer. He was a great scientist, and his research on testate amoebae - of which we quote 17 publications-was a major inspiration during the preparation of our paper. We are grateful to Juliane Seyfert and Annette Teltewskoi for assistance in the field, Stefan Goen and
Dierk Michaelis for the identification of mosses, and Martin Schrön for the construction of the three-dimensional model of the polygon. Furthermore, we thank the organisers and participants of the 2011 POLYGON Kytalyk expedition (cf. Pestryakova and Schirrmeister 2012) for logistic support and the pleasant ambiance. We thank three anonymous reviewers for valuable comments.

Author contributions PdK interpreted the dataset, wrote and designed the manuscript and most of the figures, and compiled the final version of the paper. AB performed the testate amoebae analyses, assisted in the interpretation of the dataset and in the preparation of the manuscript. MT performed and interpreted the NMDS-analyses and assisted in the preparation of the manuscript. HJ participated in the field work, conceived and supervised the research of ice-wedge polygon mires, assisted in the interpretation of the data, and edited the text of the paper. All authors read and commented on the manuscript and approved its final version.

Funding Open Access funding provided by Projekt DEAL. The research in this paper was financed by RFBR Scientific Funds [Grant Numbers 16-04-00451\18, 15-29-02518], by the German Ministry of Education and Research [CARBOPERM-Project, BMBF grant number 03G0836], and by the German Research Council [DFG; project 'Polygons in tundra wetlands: state and dynamics under climate variability in polar regions (POLYGON)', Grant Number Jo 332-14-1].

\section{Complaince with ethical standards}

Conflict of interest The authors declare that they have no conflict of interest.

Open Access This article is licensed under a Creative Commons Attribution 4.0 International License, which permits use, sharing, adaptation, distribution and reproduction in any medium or format, as long as you give appropriate credit to the original author(s) and the source, provide a link to the Creative Commons licence, and indicate if changes were made. The images or other third party material in this article are included in the article's Creative Commons licence, unless indicated otherwise in a credit line to the material. If material is not included in the article's Creative Commons licence and your intended use is not permitted by statutory regulation or exceeds the permitted use, you will need to obtain permission directly from the copyright holder. To view a copy of this licence, visit http://creativecommons.org/licenses/by/4.0/.

\section{References}

Abbott BW, Jones JB, Schuur EAG, Chapin FS III, Bowden WB, BretHarte MS, Epstein HE, Flannigan MD, Harms TK, Hollingsworth TN, Mack MC, McGuire AD, Natali SM, Rocha AV, Tank SE, Turetsky MR, Vonk JE, Wickland KP, Aiken GR, Alexander HD, Amon RMW, Benscoter BW, Bergeron Y, Bishop K, Blarquez O, Bond-Lamberty B, Breen AL, Buffam I, Cai Y, Carcaillet C, Carey SK, Chen JM, Chen HYH, Christensen TR, Cooper LW, Cornelissen JHC, De Groot WJ, DeLuca TH, Dorrepaal E, Fetcher N, Finlay JC, Forbes BC, French NHF, Gauthier S, Girardin MP, Goetz SJ, Goldammer JG, Gough L, Grogan P, Guo L, Higuera PE, Hinzman L, Hu FS, Hugelius G, Jafarov EE, Jandt R, Johnstone JF, Karlsson J, Kasischke ES, Kattner G, Kelly R, Keuper F, Kling GW, Kortelainen P, Kouki J, Kuhry P, Laudon H, Laurion I, Macdonald RW, Mann PJ, Martikainen PJ, McClelland JW, Molau U, Oberbauer SF, Olefeldt D, Paré D, Parisien MA, Payette S, Peng C, Pokrovsky OS, Rastetter EB, 
Raymond PA, Raynolds MK, Rein G, Reynolds JF, Robards M, Rogers BM, Schädel C, Schaefer K, Schmidt IK, Shvidenko A, Sky J, Spencer RGM, Starr G, Striegl RG, Teisserenc R, Tranvik LJ, Virtanen T, Welker JM, Zimov S (2016) Biomass offsets little or none of permafrost carbon release from soils, streams, and wildfire: an expert assessment. Environ Res Lett 11:034014. https://doi.org/10.1088/1748-9326/11/3/034014

Amesbury MJ, Mallon G, Charman DJ, Hughes PDM, Booth RK, Daley TJ, Garneau M (2013) Statistical testing of a new testate amoeba-based transfer function for water-table depth reconstruction on ombrotrophic peatlands in north-eastern Canada and Maine, United States. J Quat Sci 28:27-39. https://doi. org/10.1002/jqs. 2584

Amesbury MJ, Swindles GT, Bobrov A, Charman DJ, Holden J, Lamentowicz M, Mallon G, Mazei Y, Mitchell EAD, Payne RJ, Roland TP, Turner TE, Warner BG (2016) Development of a new pan-European testate amoeba transfer function for reconstructing peatland palaeohydrology. Quat Sci Rev 152:132-151. https:// doi.org/10.1016/j.quascirev.2016.09.024

Amesbury MJ, Booth RK, Roland TP, Bunbury J, Clifford MJ, Charman DJ, Elliot S, Finkelstein S, Garneau M, Hughes PDM, Lamarre A, Loisel J, Mackay H, Magnan G, Markel ER, Mitchell EAD, Payne RJ, Pelletier N, Roe H, Sullivan ME, Swindles GT, Talbot J, Van Bellen S, Warner BG (2018) Towards a Holarctic synthesis of peatland testate amoeba ecology: development of a new continental-scale palaeohydrological transfer function for North America and comparison to European data. Quat Sci Rev 201:483-500. https://doi.org/10.1016/j.quascirev.2018.10.034

Andreev AA, Lubinski DJ, Bobrov AA, Ingólfsson Ó, Forman SL, Tarasov PE, Möller P (2008) Early Holocene environments on October revolution Island, Severnaya Zemlya. Palaeogeogr Palaeoclimatol Palaeoecol 267:21-30. https://doi.org/10.1016/j. palaeo.2008.05.002

Andreev A, Tarasov P, Schwamborn G, Ilyashuk B, Ilyashuk E, Bobrov A, Klimanov V, Rachold V, Hubberten H-W (2004) Holocene paleoenvironmental records from Nikolay Lake, Lena river delta, arctic Russia. Palaeogeogr Palaeoclimatol Palaeoecol 209:197-217. https://doi.org/10.1016/j.palae o.2004.02.010

Avel E, Pensa M (2013) Preparation of testate amoebae samples affects water table depth reconstructions in peatland palaeoecological studies. Est J Earth Sci 62:113-119. https://doi. org/10.3176/earth.2013.09

Beyens L, Bobrov A (2016) Evidence supporting the concept of a regionalized distribution of testate amoebae in the Arctic. Acta Protozool 55:197-209. https://doi.org/10.4467/16890 027AP.16.019.6006

Beyens L, Chardez D (1986) Some new and rare testate amoebae from the Arctic. Acta Protozool 25:81-91

Beyens L, Chardez D (1987) Evidence from testate amoebae for changes in some local hydrological conditions between c. 5000 BP and c 3800 BP on Edgeøya (Svalbard). Polar Res. https:// doi.org/10.3402/polar.v5i2.6873

Beyens L, Chardez D (1995) An annotated list of testate amoebae observed in the Arctic between the longitudes $27^{\circ} \mathrm{E}$ and $168^{\circ} \mathrm{W}$. Arch Protistenkd 146:219-233. https://doi.org/10.1016/S0003 -9365(11)80114-4

Beyens L, Meisterfeld R (2001) Protozoa: testate amoebae. In: Smol JP, Birks HJB, Last WM (eds) Tracking environmental change using lake sediments volume 3: terrestrial, algal and siliceous indicators. Kluwer Academic Publishers, Dordrecht, pp 121-153

Beyens L, Chardez D, De Landtsheer R, De Bock P, Jacques E (1986a) Testate amoebae populations from moss and lichen habitats in the Arctic. Polar Biol 5:165-173. https://doi.org/10.1007/BF004 41696
Beyens L, Chardez D, De Landtsheer R (1986b) Testate amoebae communities from aquatic habitats in the Arctic. Polar Biol 6:197205. https://doi.org/10.1007/BF00443396

Beyens L, Chardez D, De Baere D (1990) Ecology of terrestrial testate amoebae assemblages from coastal lowlands on Devon Island (NWT, Canadian Arctic). Polar Biol 10:431-440. https://doi. org/10.1007/BF00233691

Beyens L, Ledeganck P, Graae BJ, Nijs I (2009) Are soil biota buffered against climatic extremes? An experimental test on testate amoebae in arctic tundra (Qeqertarsuaq, West Greenland). Polar Biol 32:453-462. https://doi.org/10.1007/s00300-008-0540-y

Billings WD, Peterson KM (1980) Vegetational change and icewedge polygons through the thaw-lake cycle in Arctic Alaska. Arctic Alpine Res 12:413-432. https://doi.org/10.1080/00040 851.1980.12004204

Birks HJB, Birks HH (1980) Quaternary palaeoecology. Edward Arnold, London

Bobrov AA, Wetterich S (2012) Testate amoebae of arctic tundra landscapes. Prostitology 7:51-58. https://doi.org/10.1007/s0030 0-013-1311-y

Bobrov AA, Charman DJ, Warner BG (2002) Ecology of testate amoebae from oligotrophic peatlands: specific features of polytypic and polymorphic species. Biology Bull 29:605-617. https://doi. org/10.1023/A:1021732412503

Bobrov AA, Andreev AA, Schirrmeister L, Siegert C (2004) Testate amoebae (Protozoa: Testacealobose and Testaceafilosea) as bioindicators in the Late Quaternary deposits of the Bykovsky Peninsula, Laptev Sea, Russia. Palaeogeogr Palaeoclimatol Palaeoecol 209:165-181. https://doi.org/10.1016/j.palae o.2004.02.012

Bobrov AA, Müller S, Chizikova NA, Schirrmeister L, Andreev AA (2009) Testate amoebae in late Quaternary sediments of the Cape Mamontov Klyk (Yakutia). Biol Bull 36:363-372. https://doi. org/10.1134/S1062359009040074

Bobrov AA, Wetterich S, Beermann F, Schneider A, Kokhanova L, Schirrmeister L, Pestryakova LA, Herzschuh U (2013) Testate amoebae and environmental features of polygon tundra in the Indigirka lowland (East Siberia). Polar Biol 36:857-870. https ://doi.org/10.1007/s00300-013-1311-y

Boike J, Wille C, Abnizova A (2008) Climatology and summer energy and water balance of polygonal tundra in the Lena River Delta, Siberia. J Geophys Res 113:G03025. https://doi. org/10.1029/2007JG000540

Bonnet L, Thomas R (1960) Étude sur les thécamoebiens du sol (II). Bulletin de la Société d'Histoire Naturelle de Toulouse 95:339-349

Booth R (2008) Testate amoebae as proxies for mean annual watertable depth in Sphagnum-dominated peatlands of North America. J Quat Sci 23:43-57. https://doi.org/10.1002/jqs.1114

Booth RK, Lamentowicz M, Charman DJ (2010/2011) Preparation and analysis of testate amoebae in peatland palaeoenvironmental studies. Mires Peat 7(2):1-7

Bradshaw RHW (1981) Modern pollen representation factors for woods in South-East England. J Ecol 69:45-70

Chardez D (1965) Écologie générale des Thécamobiens (Rhizopoda testaceae). Bulletin de l'Institut Agronomique et des stations de recherches de Gembloux 33:307-341

Charman DJ (2001) Biostratigraphic and palaeoenvironmental applications of testate amoebae. Quat Sci Rev 20:1753-1764. https:// doi.org/10.1016/S0277-3791(01)00036-1

Charman DJ, Warner BG (1997) The ecology of testate amoebae (Protozoa: Rhizopoda) in oceanic peatlands in Newfoundland, Canada: modelling hydrological relationships for palaeoenvironmental reconstruction. Ecoscience 4:555-562. https://doi. org/10.1080/11956860.1997.11682435 
Charman DJ, Hendon D, Woodland WA (2000) The identification of testate amoebae (Protozoa:Rhizopoda) in peats. QRA Technical Guide No. 9, Quaternary Research Association, London

Charman DJ, Caseldine C, Baker A, Geary B, Hatton J, Proctor C (2001) Paleohydrological records from peat profiles and speleothems in Sutherland, Northwest Scotland. Quat Res 55:223-234. https://doi.org/10.1006/qres.2000.2190

Charman DJ, Blundell A, Members A (2007) A new European testate amoebae transfer function for palaeohydrological reconstruction on ombrotrophic peatlands. J Quat Sci 22:209-221. https://doi. org/10.1002/jqs.1026

Chevychelov AP, Bosikov NP (2010) Natural conditions. In: Troeva EI, Isaev AP, Cherosov MM, Karpov NS (eds) The far north: plant biodiversity and ecology of Yakutia. Plant and Vegetation 3. Springer, Dordrecht, pp 1-23. https://doi. org/10.1007/978-90-481-3774-9_1

Clarke KJ (2003) Guide to the identification of soil protozoa-testate amoebae. Freshwater Biological Association/The Ferry House, Far Sawrey/Ambleside/Cumbria

Dallimore A (2004) The characteristics of thecamoebians of Arctic thermokarst lakes, Richards Island, N.W.T. J Foramin Res 4:249 257. https://doi.org/10.2113/34.4.249

De Graaf F (1956) Studies on Rotaria and Rhizopoda from the Netherlands. I. Rotaria and Rhizopoda from the "Grote Huisven". Biol Jaarb 23:145-216

De Klerk P, Donner N, Joosten H, Karpov NS, Minke M, Seifert N, Theuerkauf M (2009) Vegetation patterns, recent pollen deposition and distribution of non-pollen palynomorphs in a polygon mire near Chokurdakh (NE Yakutia, NE Siberia). Boreas 38:3958. https://doi.org/10.1111/j.1502-3885.2008.00036.x

De Klerk P, Donner N, Karpov NS, Minke M, Joosten H (2011) Short-term dynamics of a low-centred ice wedge polygon near Chokurdakh (NE Yakutia, NE Siberia) and climate change during the last ca. 1250 years. Quat Sci Rev 30:3013-3031. https:// doi.org/10.1016/j.quascirev.2011.06.016

De Klerk P, Teltewskoi A, Theuerkauf M, Joosten H (2014) Vegetation patterns, pollen deposition and distribution of non-pollen palynomorphs in an ice-wedge polygon near Kytalyk (NE Siberia), with some remarks on Arctic pollen morphology. Polar Biol 37:1393-1412. https://doi.org/10.1007/s00300-014-1529-3

De Klerk P, Theuerkauf M, Joosten H (2017) Vegetation, recent pollen deposition, and distribution of some non-pollen palynomorphs in a degrading ice-wedge polygon mire complex near Pokhodsk (NE Siberia), including size-frequency analyses of pollen attributable to Betula. Rev Palaeobot Palynol 238:122-143. https://doi. org/10.1016/j.revpalbo.2016.11.015

De Klerk P, Donner N, Minke M, Joosten H (2018) Comprehending the arctic ice-wedge polygon mire landscape using short-distance high resolution palaeoecological research. In: Sychev VG, Mueller L (eds) Novel methods and results of landscape research in Europe, Central Asia and Siberia. Volume 1: Landscapes in the 21th century: status analyses, basic processes and research concepts. Russian Academy of Sciences FSBSI "All-Russian research institute of Agrochemistry named after D.N. Pryanishnikov":257-262. https://doi.org/10.25680/6112.2018.76.43.048

Decloitre L (1962) Le genre Euglypha Dujardin. Arch Protistenkd 106:51-100

Decloitre L (1977) Le genre Nebela. Compléments à jour au 31. Décembre 1974 de la monographie du genre parue an 1936. Arch Protistenkd 119:325-352

Decloitre L (1981) Le genre Trinema Dujardin, 1841. Révision à jour au 31. Décembre 1979. Arch Protistenkd 142:193-218

Djamali M, Cilleros K (2020) Statistically significant minimum pollen count in Quaternary pollen analysis; the case of pollen-rich lake sediments. Rev Palaeobot Palynol. https://doi.org/10.1016/j. revpalbo.2019.104156
Fagerlind F (1952) The real signification of pollen diagrams. Bot Notiser 1952:185-224

Gałka M, Swindles GT, Szal M, Fulweber R, Feurdean A (2018) Response of plant communities to climate change during the late Holocene: palaeoecological insights from peatlands in the Alaskan Arctic. Ecol Indic 85:525-536. https://doi.org/10.1016/j ecolind.2017.10.062

Grospietsch T (1964) Die Gattungen Cryptodifflugia und Difflugiella (Rhizopoda testaceae). Zool Anz 172:243-257

Grospietsch T (1972) Wechseltierchen (Rhizopoden). Kosmos Verlag/ Frankckh'sche Verlagsbuchhandlung, Stuttgart

Heger TJ, Mitchell EAD, Leander BS (2013) Holarctic phylogeography of the testate amoebae Hyalosphenia papilio (Amoebozoa: Arcellinida) reveals extensive genetic diversity explained more by environment than dispersal limitation. Mol Ecol 22:51725184. https://doi.org/10.1111/mec.12449

Heiri O, Lotter AF (2001) Effect of low count sums on quantitative environmental reconstructions: an example using subfossil chironomids. J Paleolimnol 26:343-350. https://doi. org/10.1023/A:1017568913302

Hendon D, Charman DJ (1997) The preparation of testate amoebae (Protozoa: Rhizopoda) samples from peat. Holocene 7:199-205. https://doi.org/10.1177/095968369700700207

Hoogenraad HR, De Groot AA (1940) Fauna van Nederland. Aflevering IX. Zoetwaterrhizopoden en -heliozoën (A Ia). Sijthoff, Leiden

Hugelius G, Strauss J, Zubrzycki S, Harden JW, Schuur EAG, Ping C-L, Schirrmeister L, Grosse G, Michaelson GJ, Koven CD, O'Donnell JA, Elberling B, Mishra U, Camill P, Yu Z, Palmtag J, Kuhry P (2014) Estimated stocks of circumpolar permafrost carbon with quantified uncertainty ranges and identified data gaps. Biogeosciences 11:6573-6593. https://doi.org/10.5194/ bg-11-6573-2014

Ignatov MS, Afonina OM, Ignatova EA (2006) Check-list of mosses of East Eruope and North Asia. Arctoa 25:1-130

Jassey VE, Lamentowicz Ł, Robroek BJM, Gąbka M, Rusińska A, Lamentowicz M (2014) Plant functional diversity drives nichesize-structure of dominant microbial consumers along a poor to extremely rich fen gradient. J Ecol 102:1150-1162. https:// doi.org/10.1111/1365-2745.12288

Jassey VEJ, Signarbieux C, Hättenschwiller S, Bragazza L, Buttler A, Delarue F, Fournier B, Gilbert D, Laggoun-Défarge F, Lara E, Mills RTE, Mitchell EAD, Payne RJ, Robroek BJM (2015) An unexpected role for mixotrophs in the response of peatland carbon cycling to climate warming. Sci Rep 5:16931. https:// doi.org/10.1038/srep16931

Joosten H (2019) Permafrost peatlands: losing ground in a warming world. Frontiers 2018/19 Emerging issues of environmental concern. United Nations Environment Programme, Nairobi, pp 38-51

Joosten H, De Klerk P (2002) What's in a name? Some thoughts on pollen classification, identification, and nomenclature in Quaternary palynology. Rev Palaeobot Palynol 122:29-45. https:// doi.org/10.1016/S0034-6667(02)00090-8

Kanevskiy M, Shur Y, Jorgenson T, Brown DRN, Moskalenko N, Brown J, Walker DA, Raynolds MK, Buchhorn M (2017) Degradation and stabilization of ice-wedges: implications for assessing risk of thermokarst in northern Alaska. Geomorphology 297:20 42. https://doi.org/10.1016/j.geomorph.2017.09.001

Kosakyan A, Gomaa F, Lara E, Lahr DJG (2016) Current and future perspectives on the systematics, taxonomy and nomenclature of testate amoebae. Eur J Protistol 55:105-117. https://doi. org/10.1016/j.ejop.2016.02.001

Kuhry P, Grosse G, Harden JW, Hugelius G, Koven CD, Ping C-L, Schirrmeister L, Tarnocai C (2013) Characterisation of the 
permafrost carbon pool. Permafrost Periglac 24:146-155. https ://doi.org/10.1002/ppp.1782

Lamarre A, Magnan G, Garneau M, Boucher É (2013) A testate amoebae-based transfer function for paleohydrological reconstruction from boreal and subarctic peatlands in northeastern Canada. Quat Int 306:88-96. https://doi.org/10.1016/j.quaint.2013.05.054

Lamentowicz Ł, Gąbka M, Lamentowicz M (2007) Species composition of testate amoebae (Protists) and environmental parameters in a Sphagnum peatland. Pol Ecol Stud 55:749-759

Lamentowicz Ł, Lamentowicz M, Gąbka M (2008) Testate amoebae ecology and a local transfer function from a peatland in western Poland. Wetlands 28:164-175. https://doi.org/10.1672/07-92.1

Lamentowicz Ł, Gąbka M, Rusińska A, Sobczyński T, Owslany P, Lamentowicz M (2011) Testate amoebae (Arcellinida, Euglyphida) ecology along a poor-rich gradient in fens of western Poland. Inernat Rev Hydrobiol 96:356-380. https://doi.org/10.1002/ iroh.201111357

Lamentowicz M, Bragazza L, Buttler A, Jassey VEJ, Mitchell EAD (2013) Seasonal patterns of testate amoebae diversity, community structure and species-environment relationships in four Sphagnum-dominated peatlands along a $1300 \mathrm{~m}$ altitudinal gradient in Switzerland. Soil Biol Biochem 67:1-11. https://doi. org/10.1016/j.soilbio.2013.08.002

Liljedahl AK, Boike J, Daanen RP, Fedorov AN, Frost GV, Grosse G, Hinzman LD, Iijma Y, Jorgenson JC, Matveyeva N, Necsoiu M, Raynolds MK, Romanovsky VE, Schulla J, Tape KD, Walker DA, Wilson CJ, Yabuki H, Zona D (2016) Pan-Arctic ice-wedge degradation in warming permafrost and its influence on tundra hydrology. Nat Geosci 9:312-318. https://doi.org/10.1038/ngeo2 674

Lingafelter SW, Nearns EH (2013) Elucidating Article 45.6 of the International Code of Zoological Nomenclature: a dichotomous key for the determination of subspecific or infrasubspecific rank. Zootaxa 3709:597-600. https://doi.org/10.11646/zoota xa.3709.6.9

Lorencová M (2009) Thecamoebians from recent lake sediments from the Šumava Mts, Czech Republic. Bull Geosci 84:359-376. https ://doi.org/10.3140/bull.geosci.1074

Marcisz K, Lamentowicz Ł, Slowińska S, Słowiński M, Muszak W, Lamentowicz M (2014) Seasonal changes in Sphagnum peatland testate amoebae communities along a hydrological gradient. Eur J Protistol 50:445-455. https://doi.org/10.1016/j. ejop.2014.07.001

Marcisz K, Tinner W, Colombaroli D, Kołaczek P, Słowiński M, Fiałkiewicz-Kozieł B, Łokas E, Lamentowicz M (2015) Longterm hydrological dynamics and fire history over the last 2000 years in CE Europe reconstructed from a high-resolution peat archive. Quat Sci Rev 112:138-152. https://doi.org/10.1016/j. quascirev.2015.01.019

Mattheeussen R, Ledeganck P, Vincke S, Van de Vijver B, Nijs I, Beyens L (2005) Habitat selection of aquatic testate amoebae communities on Qeqertarsuaq (Disko Island), west Greenland. Acta Protozool 44:253-263

Mazei YuA, Tsyganov AN (2006) Presnovodnye rakovinnye ameby. KMK, Moscow

Mazei YA, Tsyganov AN (2007/2008) Species composition, spatial distribution and seasonal dynamics of testate amoebae community in a Sphagnum bog (Middle Volga region, Russia). Protistology 5:156-206

Mazei Y, Chernyshov V, Tsyganov AN, Payne RJ (2015) Testing the effect of refrigerated storage on testate amoebae samples. Microb Ecol 70:861-864. https://doi.org/10.1007/s00248-015-0628-1

Mazei YA, Natalia V, Lebedeva NV, Taskaeva AA, Ivanovsky AA, Chernyshov VA, Tsyganov A, Payne RJ (2018a) What role does human activity play in microbial biogeography? The revealing case of testate amoebae in the soils of Pyramiden,
Svalbard. Pedobiologia 67:10-15. https://doi.org/10.1016/j. pedobi.2018.02.002

Mazei YA, Lebedeva NV, Taskaeva AA, Ivanovsky AA, Chernyshov VA, Tsyganov AN, Payne RJ (2018b) Potential influence of birds on soil testate amoebae in the Arctic. Polar Sci 16:78-85. https ://doi.org/10.1016/j.polar.2018.03.001

Mazei YA, Tsyganov AN, Chernyshov VA, Ivanovsky AA, Payne RJ (2018c) First records of testate amoebae from the Novaya Zemlya archipelago (Russian Arctic). Polar Biol 41:1133-1142. https:// doi.org/10.1007/s00300-018-2273-x

Mediola FS, Scott DB, Collins ES, McCarthy FMG (1990) Fossil thecamoebians: present status and prospects for the future. In: Hemleben C, Kaminksi MK, Kuhnt W, Scott DB (eds) Palaeoecology, biostratigraphy, palaeoceanography and taxonomy of agglutinated foraminifera. Kluwer, Dordrecht, pp 813-839

Meyer H, Opel T, Laepple T, Dereviagin AYu, Homann K, Werner M (2015) Long-term winter warming trend in the Siberian Arctic during the mid- to late Holocene. Nat Geosci 8:122-125. https ://doi.org/10.1038/NGEO2349

Minke M, Donner N, Karpov NS, De Klerk P, Joosten H (2007) Distribution, diversity, development and dynamics of polygon mires: examples from northeast Yakutia (Siberia). Peatl Int 1(2007):36-40

Minke M, Donner N, Karpov N, De Klerk P, Joosten H (2009) Patterns in vegetation composition, surface height and thaw depth in polygon mires in the Yakutian Arctic (NE Siberia): a microtopographical characterisation of the active layer. Permafrost Periglac 20:357-368. https://doi.org/10.1002/ppp.663

Miola M (2012) Tools for Non-Pollen Palynomorphs (NPPs) analysis: a list of Quaternary NPP types and reference literature in English language (1972-2011). Rev Palaeobot Palynol 186:142-161. https://doi.org/10.1016/j.revpalbo.2012.06.010

Mitchell EAD, Gilbert D (2004) Vertical micro-distribution and response to nitrogen deposition of testate amoebae in Sphagnum. J Eukaryot Microbiol 51:480-490. https://doi. org/10.1111/j.1550-7408.2004.tb00400.x

Mitchell EAD, Borcard D, Buttler AJ, Grosvernier P, Gilbert D, Gobat J-M (2000) Horizontal distribution patterns of testate amoebae (Protozoa) in a Sphagnum magellanicum carpet. Microb Ecol 39:290-300. https://doi.org/10.1007/s002489900187

Mitchell EAD, Charman DJ, Warner BG (2008) Testate amoebae analysis in ecological and paleoecological studies of wetlands: past, present and future. Biodivers Conserv 17:2115-2137. https ://doi.org/10.1007/s10531-007-9221-3

Mitchell EAD, Lamentowicz M, Payne RJ, Mazei Y (2014) Effect of taxonomic resolution on ecological and palaeoecological inference - a test using testate amoebae water table depth transfer functions. Quat Sci Rev 91:62-69. https://doi.org/10.1016/j. quascirev.2014.03.006

Mosimann J (1965) Statistical methods for the pollen analyst: multinomial and negative multinomial techniques. In: Kummel B, Raup D (eds) Handbook of paleontological techniques. W. H Freemann, San Francisco, pp 636-673

Mulder C, Janssen CR (1998) Application of Chernobyl caesium-137 fallout and naturally occurring lead-210 for standardization of time in moss samples: recent pollen-flora relationships in the Allgäuer Alpen, Germany. Rev Palaeobot Palynol 103:23-40. https://doi.org/10.1016/S0034-6667(98)00023-2

Mulder C, Janssen CR (1999) Occurrence of pollen and spores in relation to present-day vegetation in a Dutch heathland area. J Veg Sci 10:87-100. https://doi.org/10.2307/3237164

Müller S, Bobrov AA, Schirrmeister L, Andreev AA, Tarasov PE (2009) Testate amoebae record from the Laptev Sea coast and its implication for the reconstruction of Late Pleistocene and Holocene environments in the Arctic Siberia. 
Palaeogeogr Palaeoclimatol Palaeoecol 271:301-315. https:// doi.org/10.1016/j.palaeo.2008.11.003

Oksanen JF, Blanchet G, Kindt R, Legendre P, Minchin PR, O'Hara RB, Simpson GL, Solymos P, Stevens MHH, Wagner H (2016) vegan: Community Ecology Package. R package version 2.3-5. https://cran.r-project.org/web/packages/vegan/index.html

Oliverio AM, Lahr DJ, Nguyen T, Katz LA (2014) Crypticdiversity within morphospecies of testate amoebae (Amoebozoa: Arcellinida) in New England bogs and fens. Protist 165:196-207. https ://doi.org/10.1016/j.protis.2014.02.001

Patterson RT, Roe HM, Swindles GT (2012) Development of an Arcellaceae (testate lobose amoebae) based transfer function for sedimentary phosphorus in lakes. Palaeogeogr Palaeoclimatol Palaeoecol 348(349):32-44. https://doi.org/10.1016/j.palae o.2012.05.028

Payne RJ (2012) Volcanic impacts on peatland microbial communities: a tephropalaeoecological hypothesis-test. Quat Int 268:98-110. https://doi.org/10.1016/j.quaint.2011.06.019

Payne RJ (2013) Seven reasons why protists make useful bioindicators. Acta Protozool 52:105-113. https://doi.org/10.4467/16890 027AP.13.0011.1108

Payne RJ, Mitchell EAD (2009) How many is enough? Determining optimal count totals for ecological and palaeoecological studies of testate amoebae. J Paleolimnol 42:483-495. https://doi. org/10.1007/s10933-008-9299-y

Payne RJ, Pates JM (2009) Vertical stratification of testate amoebae in the Elatia Mires, northern Greece: palaeoecological evidence for a wetland response to recent climatic change, or autogenic processes? Wetl Ecol Manag 17:355-364. https://doi.org/10.1007/ s11273-008-9112-8

Payne RJ, Kishaba K, Blackford JJ, Mitchell EAD (2006) Ecology of testate amoebae (Protista) in south-central Alaska peatlands: building transfer-function models for palaeoenvironmental studies. Holocene 16:403-414. https://doi.org/10.1191/0959683606 h1936rp

Payne RJ, Lamentowicz M, Mitchell EAD (2011) The perils of taxonomic inconsistency in quantitative palaeoecology: experiments with testate amoebae data. Boreas 40:15-27. https://doi.org/10.1 111/j.1502-3885.2010.00174.x

Payne RJ, Lamentowicz M, Van der Knaap WO, Van Leeuwen JFN, Mitchell EAD, Mazei Y (2012) Testate amoebae in pollen slides. Rev Palaeobot Palynol 173:68-79. https://doi.org/10.1016/j. revpalbo.2011.09.006

Payne RJ, Babeshko KV, Van Bellen S, Blackford JJ, Booth RK, Charman DJ, Ellershaw MR, Gilbert D, Hughes PDM, Jassey VEJ, Lamentowicz Ł, Lamentowicz M, Malysheva EA, Mauquoy D, Mazei Y, Mitchell EAD, Swindles GT, Tsyganov AN, Turner TE, Telford RJ (2016) Significance testing testate amoebae water table reconstructions. Quat Sci Rev 138:131-135. https://doi. org/10.1016/j.quatscirev.2016.01.030

Penard ME (1890) Études sur les rhizopodes d'eau douce. Mém Soc Phys Hist Nat Genève 31:1-230

Pestryakova L, Schirrmeister L (2012) Introduction. Ber Polarforsch Meeresforsch 653:1-4

Petrescu AMR, Van Huissteden J, Jackowicz-Korczynski M, Yurova A, Christensen TR, Crill PM, Bäckstrand K, Maximov TC (2008) Modelling $\mathrm{CH}_{4}$ emissions from arctic wetlands: effects of hydrological parameterization. Biogeosciences 5:111-121. https://doi. org/10.5194/bg-5-111-2008

Portsmuth A, Avel-Niinemets E, Pensa M (2011) Distribution of testate amoebae along a gradient hummock-lawn-hollow in a Sphagnum bog: potential implications for palaeoecological reconstructions. Pol J Ecol 59:551-566

Prentice IC, Webb T III (1986) Pollen percentages, tree abundances and the Fagerlind effect. J Quat Sci 1:35-43. https://doi.org/10.1002/ jqs.3390010105
Price J (1997) Soil moisture, water tension and water level relationships in a managed cutover bog. J Hydrol 292:21-32. https://doi. org/10.1016/S0022-1694(97)00037-1

Räsänen S, Hicks S, Odgaard BV (2004) Pollen deposition in mosses and in a modified 'Tauber trap' from Hailuoto, Finland: what exactly do the mosses record? Rev Palaeobot Palynol 129:103116. https://doi.org/10.1016/j.revpalbo.2003.12.001

Rauenbusch K (1987) Biologie und Feinstruktur (REM-Untersuchungen) terrestrischer Testaceen in Waldböden (Rhizopoda, Protozoa). Arch Protistenkd 134:191-294. https://doi.org/10.1016/ S0003-9365(87)80073-8

Schädel C, Bader MKF, Schuur EAG, Biasi C, Bracho R, Capek P, De Baets S, Diáková K, Ernakovich J, Estop-Aragones C, Graham DE, Hartley IP, Iversen CM, Kane E, Knoblauch C, Lupascu M, Martikainen PJ, Natali SM, Norby RJ, O'Donnell JA, Chowdhury TR, Šantrucková H, Shaver G, Sloan VL, Treat CC, Turetsky MR, Waldrop MP, Wickland KP (2016) Potential carbon emissions dominated by carbon dioxide from thawed permafrost soils. Nat Clim Change 6:950-953. https://doi.org/10.1038/ NCLIMATE3054

Schirrmeister L, Siegert C, Kuznetsova T, Kuzmina S, Andreev A, Kienast F, Meyer H, Bobrov A (2002) Paleoenvironmental and paleoclimatic records from permafrost deposits in the Arctic region of northern Siberia. Quat Int 89:97-118. https://doi.org/10.1016/ S1040-6182(01)00083-0

Schirrmeister L, Grosse G, Schnelle M, Fuchs M, Krbetschek M, Ulrich M, Kunitsky V, Grigoriev M, Andreev A, Kienast F, Meyer H, Babiy O, Klimova I, Bobrov A, Wetterich S, Schwamborn $\mathrm{G}$ (2011) Late quaternary paleoenvironmental records from the western Lena Delta, Arctic Siberia. Palaeogeogr Palaeoclimatol Palaeoecol 299:175-196. https://doi.org/10.1016/j.palae o.2010.10.045

Schönborn W (1964) Bodenbewohnende Testaceen aus Deutschland II. Untersuchungen in der Umgebung des Großen Stechlinsees (Brandenburg). Limnologica 2:491-499

Schönborn W (1966) Beschalte Amöben (Testacea). Ziemsen, Wittenberg Lutherstadt

Schönborn W (1992) Adaptive polymorphism in soil-inhabiting testate amoebae (Rhizopoda): its importance for delimitation and evolution of asexual species. Arch Protistenkd 142:139-155. https:// doi.org/10.1016/S0003-9365(11)80077-1

Schönborn W, Peschke P (1990) Evolutionary studies on the AssulinaValkanovia complex (Rhizopoda, Testaceafilosia) in Sphagnum and soil. Biol Fertil Soils 9:95-100. https://doi.org/10.1007/ BF00335790

Schönborn W, Petz W, Wanner M, Foissner W (1987) Observations on the morphology and ecology of the soil-inhabiting testate amoebae Schoenbornia humicola (SChÖNBorn, 1964) DeCloITRE, 1964 (Protozoa, Rhizopoda). Arch Protistenkd 134:315-330. https:// doi.org/10.1016/S0003-9365(87)80004-0

Screen JA, Deser C, Simmonds I (2012) Local and remote controls on observed Arctic warming. Geophys Res Lett 39:L10709. https:// doi.org/10.1029/2012GL051598

Sim TG, Swindles GT, Morris PJ, Gałka M, Mullan D, Galloway JM (2019) Pathways for ecological change in Canadian High Arctic wetlands under rapid twentieth century warming. Geophys Res Lett 64:726-4737. https://doi.org/10.1029/2019GL082611

Streletskiy DA, Sherstiukov AB, Frauenfeld OW, Nelson FE (2015) Changes in the 1963-2013 shallow ground thermal regime in Russian permafrost regions. Environ Res Lett 10:125005. https ://doi.org/10.1088/1748-9326/10/12/125005

Succow M, Stegmann H (2001) Nährstoffökologisch-chemische Kennzeichnung. In: Succow M, Joosten H (eds) Landschaftsökologische Moorkunde. E. Schweizerbart'sche Verlagsbuchhandlung (Nägele u. Obermiller), Stuttgart, pp 75-85 
Sullivan ME, Booth RK (2011) The potential influence of short-term environmental variability on the composition of testate amoeba communities in Sphagnum peatlands. Microb Ecol 62:80-93

Swindles GT, Morris PJ, Mullan D, Watson EJ, Turner TE, Roland TP, Amesbury MJ, Kokfelt U, Schoning K, Pratte S, Gallego-Sala A, Charman DJ, Sanderson N, Garneau M, Carrivick JL, Woulds C, Holden J, Parry L, Galloway JM (2015a) The long-term fate of permafrost peatlands under rapid climate warming. Nat Sci Rep 5:17951. https://doi.org/10.1038/srep17951

Swindles GT, Amesburry MJ, Turner TE, Carrivick JL, Woulds C, Raby C, Mullan D, Roland TP, Galloway JM, Parry L, Kokfelt U, Garneau M, Charman DJ, Holden J (2015b) Evaluating the use of testate amoebae for palaeohydrological reconstruction in permafrost peatlands. Palaeogeogr Palaeoclimatol Palaeoecol 424:111-122. https://doi.org/10.1016/j.palaeo.2015.02.004

Swindles GT, Holden J, Raby CL, Turner TE, Blundell A, Charman DJ, Menberu MW, Kløve B (2015c) Testing peatland water-table depth transfer functions using high-resolution hydrological monitoring data. Quat Sci Rev 120:107-117. https://doi.org/10.1016/j. quascirev.2015.04.019

Taylor LS, Swindles GT, Morris PJ, Gałka M (2019) Ecology of peatland testate amoebae in the Alaskan continuous permafrost zone. Ecol Indic 96:153-162. https://doi.org/10.1016/j.ecoli nd.2018.08.049

Tchebakova NM, Parfenova E, Soja AJ (2009) The effects of climate, permafrost and fire on vegetation change in Siberia in a changing climate. Environ Res Lett 4:045013. https://doi. org/10.1088/1748-9326/4/4/045013

Teltewskoi A, Seyfert J, Joosten H (2012) Records from the model polygon Lhc-11 for modern and palaeoecological studies. Ber Polarforsch Meeresforsch 653:51-60

Teltewskoi A, Beermann F, Beil I, Bobrov A, de Klerk P, Lorenz S, Lüder A, Michaelis D, Joosten H (2016) 4000 years of changing wetness in a permafrost polygon peatland (Kytalyk, NE Siberia): a comparative high-resolution multi-proxy study. Permafrost Periglac 27:76-95. https://doi.org/10.1002/ppp.1869

Tsyganov AN, Nijs I, Beyens L (2011) Does climate warming stimulate or inhibit soil protist communities? A test on testate amoebae in high-arctic tundra with free-air temperature increase. Protist 162:237-248. https://doi.org/10.1016/j.protis.2010.04.006

Tsyganov AN, Embulaeva EA, Mazei Y (2012a) Distribution of soil testate amoebae assemblages along catenas in the northern taiga zone (Karelia, Russia). Protistology 7:71-78

Tsyganov AN, Temmerman S, Ledeganck P, Beyens L (2012b) The distribution of soil testate amoebae under winter snow cover at the plot-scale level in Arctic tundra (Qeqertarsuaq/Disko Island, West Greenland). Acta Protozool 51:155-167. https:// doi.org/10.4467/16890027AP.12.012.0516

Tsyganov AN, Aerts R, Nijs I, Cornelissen JHC, Beyens L (2012c) Sphagnum-dwelling testate amoebae in Subarctic bogs are more sensitive to soil warming in the growing season than in winter: the results of eight-year field climate manipulations. Protist 163:400-414. https://doi.org/10.1016/j.protis.2011.07.005

Tsyganov AN, Milbau A, Beyens L (2013) Environmental factors influencing soil testate amoebae in herbaceous and shrubby vegetation along an altitudinal gradient in subarctic tundra (Abisko, Sweden). Eur J Protistol 49:238-248. https://doi. org/10.1016/j.ejop.2012.08.004

Tumskoy V, Schirrmeister L (2012) Study area, geological and geographical characteristics. Ber Polarforsch Meeresforsch 653:5-10

Van Huissteden, J (2020) Thawing permafrost. Permafrost carbon in a warming Arctic. Springer, Cham, 508 p. https://doi. org/10.1007/978-3-030-31379-1

Van Bellen S, Mauquoy D, Payne RJ, Roland TP, Hughes PDM, Daley TJ, Loadere NJ, Street-Perrotte A, Rice EM, Pancottog VA (2017) An alternative approach to transfer functions? Testing the performance of a functional trait-based model for testate amoebae. Palaeogeogr Palaeoclimatol Palaeoecol 468:173-183. https://doi.org/10.1016/j.palaeo.2016.12.005

Van Leeuwen J, Lamentowicz M, Van der Knaap P (2008) Testate amoebae in peat encountered in pollen slides. In: Maritan M, Miola A (eds) 3rd international workshop on quaternary nonpollen palynomorphs program, Abstract. Padua University, Padua, p 66

Walker DA, Raynolds MK, Daniëls FJ, Einarsson E, Elvebakk A, Gould WA, Katenin AE, Kholod SS, Markon CJ, Melnikov ES (2005) The circumpolar Arctic vegetation map. J Veg Sci 16:267-282. https://doi.org/10.1111/j.1654-1103.2005.tb02365.x

Weiss N, Blok D, Elberling B, Hugelius G, Jørgensen CJ, Siewert MB, Kuhry P (2016) Thermokarst dynamics and soil organic matter characteristics controlling initial carbon release from permafrost soils in the Siberian Yedoma region. Sediment Geol 340:38-48. https://doi.org/10.1016/j.sedgeo.2015.12.004

Wetterich S, Grosse G, Schirrmeister L, Andreev AA, Bobrov AA, Kienast F, Bigelow NH, Edwards ME (2012) Late Quaternary environmental and landscape dynamics revealed by a pingo sequence on the northern Seward Peninsula, Alaska. Quat Sci Rev 39:26-44. https://doi.org/10.1016/j.quascirev.2012.01.027

Zibulski R, Herzschuh U, Pestryakova LA, Wolter J, Müller S, Schilling N, Wetterich S, Schirrmeister L, Tian F (2013) River flooding as a driver of polygon dynamics: modern vegetation data and a millennial peat record from the Anabar River Lowlands (Arctic Siberia). Biogeosciences 10:5703-5728. https://doi.org/10.5194/ bg-10-5703-2013

Zoltai SC, Pollet FC (1983) Wetlands in Canada: their classification, distribution, and use. In: Gore AJP (ed) Mires: swamp, bog, fen and moors. Ecosystems of the world 4b. Elsevier, Amsterdam, pp 245-268

Zonneveld IS (1995) Land ecology: An introduction to landscape ecology as a base for land evaluation, land management and conservation. SPB Academic Publishing, Amsterdam

Publisher's Note Springer Nature remains neutral with regard to jurisdictional claims in published maps and institutional affiliations. 